\title{
Ocean structure and climate (Eastern North Atlantic): in situ measurement and remote sensing (altimeter)
}

\author{
Robin Pingree \\ Institute of Marine Studies, University of Plymouth, Drake Circus, Plymouth, PL4 8AA. Marine Biological Association, \\ The Laboratory, Citadel Hill, Plymouth, PL12PB. E-mail: irp2@unixmail.nerc-pml.ac.uk
}

\begin{abstract}
Structure and climate of the east North Atlantic are appraised within a framework of in situ measurement and altimeter remote sensing from $0^{\circ}-60^{\circ} \mathrm{N}$. Long zonal expendable bathythermograph/conductivitytemperature-depth probe sections show repeating internal structure in the North Atlantic Ocean. Drogued buoys and subsurface floats give westward speeds for eddies and wavelike structure. Records from longterm current meter deployments give the periodicity of the repeating structure. Eddy and wave characteristics of period, size or wavelength, westward propagation speed, and mean currents are derived at $20^{\circ} \mathrm{N}, 26^{\circ} \mathrm{N}$, $32.5^{\circ} \mathrm{N}, 36^{\circ} \mathrm{N}$ and $48^{\circ} \mathrm{N}$ from in situ measurements in the Atlantic Ocean. It is shown that ocean wave and eddy-like features measured in situ correlate with altimeter structure. Interior ocean wave crests or cold dome-like temperature structures are cyclonic and have negative surface altimeter anomalies; mesoscale internal wave troughs or warm structures are anticyclonic and have positive surface height anomalies. Along the Eastern Boundary, flows and temperature climate are examined in terms of sla and North Atlantic Oscillation (NAO) Index. Longterm changes in ocean climate and circulation are derived from sla data. It is shown that longterm changes from 1992 to 2002 in the North Atlantic Current and the Subtropical Gyre transport determined from sla data correlate with winter NAO Index such that maximum flow conditions occurred in 1995 and 2000. Minimum circulation conditions occurred between 1996-1998. Years of extreme negative winter NAO Index result in enhanced poleward flow along the Eastern Boundary and anomalous winter warming along the West European Continental Slope as was measured in 1990, 1996, 1998 and 2001.
\end{abstract}

\section{INTRODUCTION}

The goals of this study are to describe the ocean structure (eddies and Rossby Waves) and climate (transport and circulation) for the Eastern North Atlantic using both in situ measurement and altimeter remote sensing data. Altimeter Sea level Anomaly (sla) travel curves for westward propagating ocean structures are well-known (Tokmakian \& Challenor, 1993) and have been variously described as revealing westward propagating Rossby Waves (Chelton \& Schlax, 1996; Born et al., 1998; Cipollini et al., 1997), eddies (Pingree \& Sinha, 1998) or eddies with wavelike properties (Pingree \& Sinha, 2001). Related structures are also evident in infra-red sea surface temperature data (Halliwell \& Cornillon, 1991; Halliwell et al., 1991) and ocean colour (Pingree et al., 1999a; McGillicuddy et al., 2001) and it has been postulated that planetary Rossby Waves may be important in pumping nutrients to ocean surface waters (Uz et al., 2001; Siegel, 2001). Although westward propagating ocean colour structure is a global phenomenon (Cipollini et al., 2001), in the North Atlantic, the annual seasonal cycle dominates. At $\sim 33^{\circ} \mathrm{N}$ in the North Atlantic (one of the 'eddy-wave' latitude travel curves considered in this paper), the westward propagating SeaWiFS chlorophyll- $a$ structure can change the local timing of the spring bloom peak by two months and this effect occurs mainly in the Western Basin or west of the Mid-Atlantic Ridge. In tropical and equatorial regions (West African Upwelling, Guinea Upwelling, along the equators and off and to the west of the Congo Cone $\left.\left(4^{\circ} \mathrm{S}-5^{\circ} \mathrm{S}\right)\right)$ the semi-annual signal can become dominant. In Pingree et al. (2002) it is shown that sla structure correlated positively with changes in depth of isotherms due to the passage of deep cyclonic and anticyclonic structure in the Subtropical North Atlantic. It was also shown that the annual and semi-annual sla components could be used to derive the timing of the SeaWiFS seasonal chlorophyll- $a$ maximum in equatorial and tropical regions from seasonal variations in ocean circulation due to seasonal wind stress. Here, we present in situ measurements of westward moving eddies and wavelike structure in the Eastern North Atlantic Ocean (Figure 1) within a framework of remote sensing sla structure to determine the characteristic of eddies and waves in a general region of weak mean surface circulation (Fratantoni, 2001) and deep currents (Dickson et al., 1985; Saunders, 1998). When this has been done we will be in a better position to say what the remote sensing data are revealing, e.g. Rossby Waves, variations in ocean current strength, current meanders, fronts, eddies or wavelike eddies (Cipollini et al., 2000; Cromwell et al., 1996; Pingree et al., 1999a) and how these structures interact with biological fields (Garcia-Soto et al., 2002). Both eddies and waves may travel westward at speeds given by the phase speed for long non-dispersive Rossby Waves (Cushman-Roisin et al., 1990; Gill, 1982) so a distinction between eddies and waves based on a more detailed appraisal of the vorticity field to determine corrections 


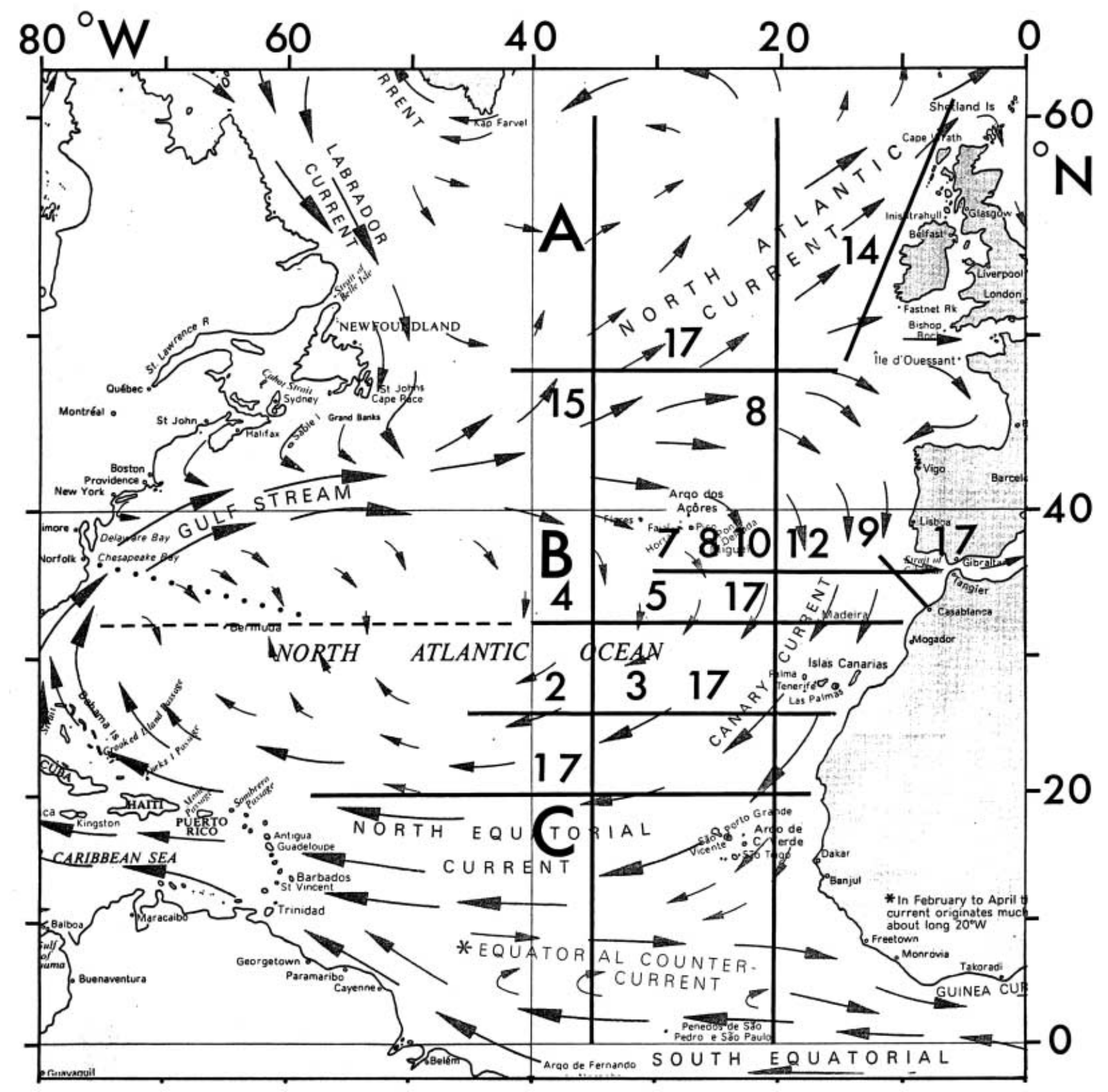

Figure 1. Map of the North Atlantic Ocean showing positions of sections (bold lines) considered. Numbers refer to the figures where the data are examined or analysed. Climate and structure on the extended line (dashed) at $32.5^{\circ} \mathrm{N}$ is described in Pingree et al. (2002). The track of HMS 'Hecla' from Norfolk to the $32.5^{\circ} \mathrm{N}$ latitude is shown dotted. A, B and C are positions where longterm sla data were derived to examine ocean circulation and climate change.

for the westward phase speed of Rossby Waves (Killworth et al., 1997) is not pursued here. Eddies have a remote sensing signature if the swirl currents extend to the sea surface with a Taylor Column structure (Taylor, 1921) above the eddy core. At present, the in situ data analysed are insufficient to discuss northward (for cyclonic) and southward (for anticyclonic) motion of vortices (e.g. Rossby, 1948) due to variations of the Coriolis parameter with latitude (beta effect) or to distinguish between eddies and waves due to nonlinearity with faster westward speed for anticyclones than cyclones (McWilliams \& Flierl, 1979; Mied \& Lindemann, 1979; Pingree \& Sinha, 2001). Eddies have wavelike properties and this duality of character means that the terminology in use to describe the in situ observations is not completely satisfactory. Some of the long hydrographic sections presented here are wavelike and a 'Rossby Wave' label is appropriate to convey the westward propagating properties of the periodic disturbances. However, westward propagating eddies with wavelike properties need a description that flags the fact that the eddy carries some water westward at the eddy speed, a 'Rossby-Taylor Wave' perhaps. In the north-east Atlantic along the continental slope margin, sla structure, slope currents and temperature structure are discussed in terms of NAO (North Atlantic Oscillation) Index. Longterm trends in sla data are discussed in terms of stored buoyancy and dynamic height and are used to derive changes in ocean circulation or climate from 1992-2002. 


\section{METHODS}

This paper uses data gathered on several cruises and from Lagrangian deployments in the north-east Atlantic Ocean and these in situ measurements are appraised within a framework of remote sensing data. The in situ data include expendable bathythermograph (XBT) and conductivity-temperature-depth probe (CTD) profiles which were calibrated and combined to produce long, essentially zonal, cross-sections of the North Atlantic Ocean. The XBT T5 profiles were calibrated (Boyd \& Linzell, 1993) with CTD casts and with a bucket sea surface temperature for each of the $\sim 260$ profiles obtained on the HMS 'Hecla' North Atlantic crossing. Description of the data and data processing procedures can be found in the references given. Data from current meter moorings deployed over long periods $(\sim 2$ years $)$ provide firm Eulerian measurements for examining changes of structure with time at key points in the ocean. Ocean current data are displayed as progressive vector diagrams, PVDs, as this integrated presentation acts as a filter, more readily identifying longer period waves or eddy structure. For instrument calibrations, deployment and recovery techniques, and data processing procedures the reader is referred to technical or cruise reports (e.g. PML, 1990, 1992, 1994, 1995). The paper relies on a comprehensive Lagrangian data set and descriptions of Argos drogued buoy assemblies, ALACE and RAFOS floats are given in earlier papers (e.g. Davis et al., 1992). Much of the early oceanographic knowledge on eddies or eddy-like structure, including instrumentation and modelling has been collected together in Eddies in Marine Science (ed. Robinson, 1983). Further developments have resulted with advances and application of remote sensing methods, see for example Richardson (1983) on Gulf Stream Rings, not covered in this present work. Finally, the results here are appraised with remote sensing data, mainly altimeter data from the ERS $1 / 2$ and Topex/ Poseidon missions. The altimeter data are presented to support conclusions derived from sea measurements because the global coverage remote sensing provides plots or maps of sea level anomaly, sla, an ideal framework to display the more limited in situ measurements with inherent ocean variability. Some workers only use sla distributions and there is an extensive sla literature so the methods here provide insight into what the radar altimeter surface measurements are revealing about the internal structure of the ocean (e.g. Kelly \& Watts, 1994; Pingree et al., 2002). The data processing methods and sla tracking techniques are given in Pingree \& Sinha (1998) and Pingree et al., (1999a) and Fourier analysis of sla in time has been used to determine the periods of dominant structure at different latitudes and longitudes. ESAs ERS-1 and ERS-2 data, and CNES/NASA TOPEX/POSEIDON data for CLS 'MSLA' products were also used, even if not displayed, and for these data processing procedures the reader is referred to AVISO (1996), Le Traon et al. (1995) and Le Traon et al. (1998). Spurious data (or $\mathrm{M}_{4}, \mathrm{M}_{2}$ tidal aliasing) with periods $\sim 31$ days and $\sim 62$ days were discarded. The sla data are used to determine the North Atlantic climate changes in circulation over the period 1992-2002. This was done by separating the thermodynamic or non-dynamic annual buoyancy signal from the 9-y time series. WOA94 data (Levitus \& Boyer, 1994) were used to support the hydrographic sections but only one section is displayed.

The abbreviation sla for sea level anomaly is used as a noun, singular or plural, and as an adjective. Metres and dbars are used for depth but a conversion is applied where appropriate (Saunders, 1981). Speeds are given in $\mathrm{ms}^{-1}$, $\mathrm{cm} \mathrm{s}^{-1}, \mathrm{kn}, \mathrm{km} \mathrm{d}^{-1}$ according to the intended meaning (i.e. scientific, navigational, descriptive or technical). Day of the year is given as yearday or YD. Since the current meter records can span three different years, a single year is usually selected. For example, yearday 366 (1994), abbreviated to YD366, is 1 January 1995. For the longer sla time series, Julian Day or JD is used (see Wilimovsky, 1990) and a conversion to year is given in the diagrams. Both zonal and eastward, and meridional and northward are used. When a particular type of eddy is first described its abbreviated name is given in full. When an eddy is referred to by letter more than once e.g. SO or TO, it will be the same eddy that is being referred to even if the discussion takes place in a different section or diagram, but $S 1$ or $T 1$ will be different eddies.

\section{RESULTS}

The in situ measurements and sla results of westward propagating ocean structure are taken in order of latitude. Rapid climate change or fluctuation conditions seen in the data is examined subsequently.

\section{Measurements and data at $\sim 20^{\circ} \mathrm{W}$}

Lagrangian measurements in the Subtropical Gyre showed that in the region between $16.5^{\circ}-21.1^{\circ} \mathrm{N}$ the return flow in the Subtropical Gyre at $\sim 200 \mathrm{~m}$ depth was $\sim 6 \mathrm{~cm} \mathrm{~s}^{-1}$ in the North Equatorial Current, between $\sim 30^{\circ}-50^{\circ} \mathrm{W}$. This result, which is time dependent (see later), is based on $\sim 600$ days of integrated measurements, 200 days from Argos buoy 3919 (Pingree, 1997) in 1994/ 1995 and $\sim 400$ days from ALACE 25972 in 1999/2000, Table 1 . The position values in Table 1 were taken from much longer Lagrangian tracks. Buoy 3919 was drogued for 929 days in the Subtropical Gyre; ALACE 25972 has been transmitting its temperature and position in the Subtropical Gyre for $\sim 7$ years. Sla travel curves, which are described fully with data in the next sections, were derived at $20^{\circ} \mathrm{W}$ and gave a westward speed of $5.5 \mathrm{~cm} \mathrm{~s}^{-1}$ for westward propagating structure with a dominant periodicity of $\sim 100$ days.

\section{Waves and eddies at $24-27^{\circ} \mathcal{N}$ (Swesty)}

The results of the hydrographic survey and structure of the eddy found near $26^{\circ} \mathrm{N}, 33^{\circ} \mathrm{W}$ in December 1993 defining a Swesty are given in full in Pingree (1996). A SWESTY is a Shallow Subtropical anticyclonic WESTward propagating eddY. There has only been one survey of a Swesty and this eddy had a core temperature of $\sim 20^{\circ} \mathrm{C}$ at $\sim 160 \mathrm{~m}$ depth where the isotherm spacing increased markedly. At $\sim 200 \mathrm{~m}$ depth, the Brunt-Vaisala Frequency, $\mathrm{N}$, is typically $\mathrm{N}=3 \mathrm{cph}$ but it can be as low as $\mathrm{N} \sim 1$ cph in the Swesty core. This anticyclonic eddy was relatively small with maximum azimuthal currents of $16 \mathrm{~cm} \mathrm{~s}^{-1}$ at a radius of $30 \mathrm{~km}$ making similar eddies difficult to detect at sea. The 
Table 1. Lagrangian measurements in the Subtropical Gyre and north-east Atlantic.

\begin{tabular}{|c|c|c|c|c|c|c|}
\hline $\begin{array}{c}\text { Argos Buoy } \\
\text { or Subsurface } \\
\text { Float }\end{array}$ & $\begin{array}{c}\text { Drogue } \\
\text { depth m or } \\
\text { float depth m }\end{array}$ & $\begin{array}{c}\text { Start } \\
\text { yearday/year } \\
\text { position }{ }^{\circ} \mathrm{N}^{\circ} \mathrm{W}\end{array}$ & $\begin{array}{c}\text { End } \\
\text { yearday/year } \\
\text { position }{ }^{\circ} \mathrm{N}^{\circ} \mathrm{W}\end{array}$ & $\begin{array}{l}\text { Selected duration } \\
\text { of Lagrangian } \\
\text { Study (days) }\end{array}$ & $\begin{array}{l}\text { Speed south } \\
\text { and west } \\
\left(\mathrm{cm} \mathrm{s}^{-1}\right)\end{array}$ & $\begin{array}{c}\text { Data Region } \\
\text { Source }\end{array}$ \\
\hline $\begin{array}{c}\text { ARGOS } \\
3919\end{array}$ & 200 & $\begin{array}{l}230 / 1994 \\
21.115 \\
37.415\end{array}$ & $\begin{array}{c}090 / 1995 \\
19.662 \\
50.444\end{array}$ & 225 & $\begin{array}{l}0.8 \\
7.0\end{array}$ & $\begin{array}{c}\mathcal{N} E C \\
\text { Pingree }\end{array}$ \\
\hline $\begin{array}{l}\text { ALACE } \\
25972\end{array}$ & 180 & $\begin{array}{c}174 / 1999 \\
16.904 \\
27.725\end{array}$ & $\begin{array}{c}189 / 2000 \\
16.492 \\
44.156\end{array}$ & 380 & $\begin{array}{l}0.1 \\
5.3\end{array}$ & $\begin{array}{c}\mathcal{N E C} \\
\text { Pingree }\end{array}$ \\
\hline $\begin{array}{c}\text { ARGOS } \\
3346 / 3915\end{array}$ & 200 & $\begin{array}{l}115 / 1993 \\
25.63 \\
24.83\end{array}$ & $\begin{array}{l}255 / 1994 \\
24.38 \\
41.33\end{array}$ & 505 & $\begin{array}{l}0.3 \\
3.8\end{array}$ & $\begin{array}{l}\text { Swesty } \\
\text { Pingree }\end{array}$ \\
\hline $\begin{array}{c}\text { ARGOS } \\
25687 / 1811\end{array}$ & 200 & $\begin{array}{c}295 / 1995 \\
32.324 \\
33.327\end{array}$ & $\begin{array}{l}233 / 1996 \\
33.004 \\
41.106\end{array}$ & 303 & $\begin{array}{r}-0.3 \\
2.8\end{array}$ & $\begin{array}{l}\text { Storm } 0 \\
\text { Pingree }\end{array}$ \\
\hline $\begin{array}{c}\text { ARGOS } \\
\text { 5030/5031 } \\
\text { ALACE }\end{array}$ & $\begin{array}{l}1000 / 750 \\
710 / 1100\end{array}$ & $\begin{array}{c}008 / 1994 \\
38.37 \\
9.98\end{array}$ & $\begin{array}{l}341 / 1994 \\
35.43 \\
15.38\end{array}$ & 333 & $\begin{array}{l}1.1 \\
1.7\end{array}$ & $\begin{array}{l}\text { meddy } \\
\text { Pinball } \\
\text { Pingree }\end{array}$ \\
\hline $\begin{array}{c}21076 / 21077 \\
\text { RAFOS } \\
136 / 137\end{array}$ & $1110 / 935$ & & & & & Richardson \\
\hline $\begin{array}{c}\text { ARGOS } \\
3350\end{array}$ & 45 & $\begin{array}{c}308 / 1995 \\
49.906 \\
9.660\end{array}$ & $\begin{array}{c}211 / 1996 \\
60.583 \\
-1.791\end{array}$ & 268 & $\begin{array}{l}-5.1 \\
-3.1\end{array}$ & $\begin{array}{c}\text { Slope } \\
\text { Current } \\
\text { Pingree/BODC }\end{array}$ \\
\hline
\end{tabular}

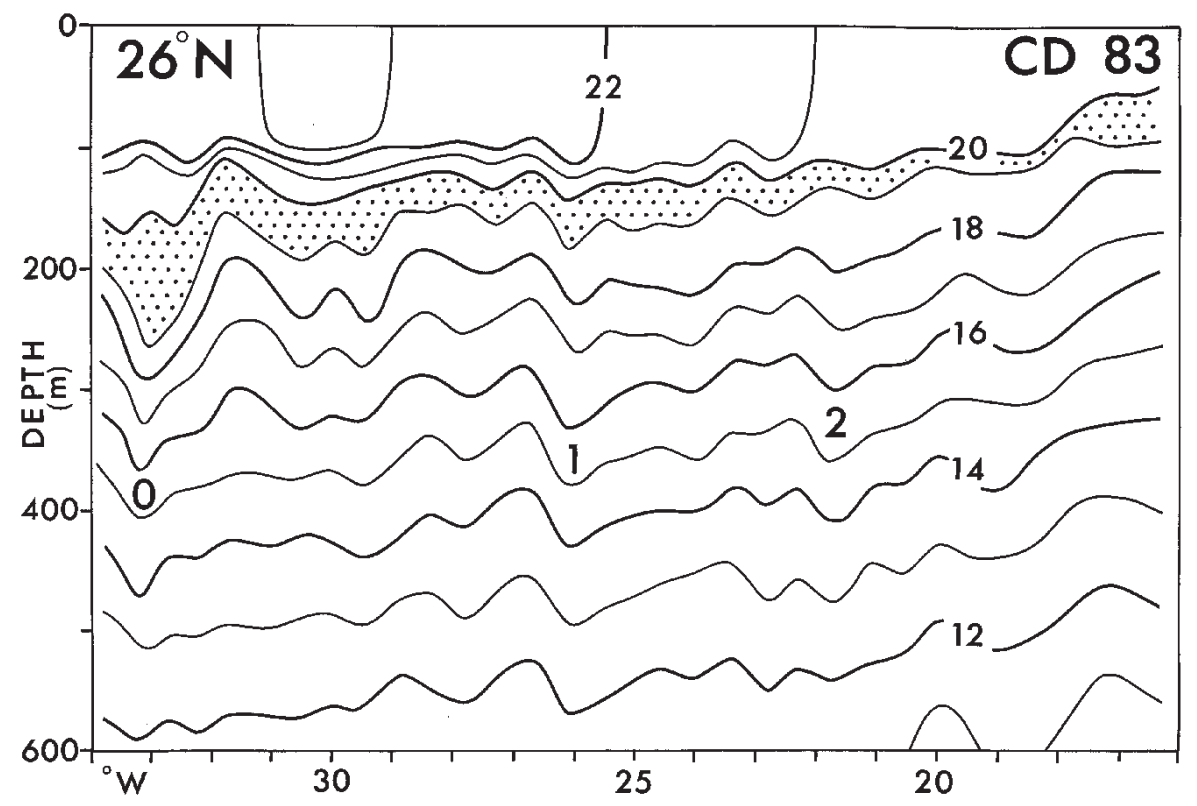

Figure 2. CD $83 \mathrm{XBT} / \mathrm{CTD}$ temperature $\left({ }^{\circ} \mathrm{C}\right)$ section $(\sim 33$ profiles $)$ at $\sim 25.7^{\circ} \mathrm{N}$ in December 1993 showing isotherms against longitude and depth descending westward in the Subtropical Gyre. Swesty is evident at $33^{\circ} \mathrm{W}$ (thickening of isotherms in the temperature band $19-20^{\circ} \mathrm{C}$ shaded). Structure is also evident near $26^{\circ} \mathrm{W}$ and $21^{\circ} \mathrm{W}$ (see Figure 3 ). Troughs of the wave-like structures are denoted $0,1,2$.

Figure 3. Westward propagating anomalies (sla in $\mathrm{mm}$ ) at $26^{\circ} \mathrm{N}$ against Julian Day (8-y period) and longitude $\left(15-45^{\circ} \mathrm{W}\right)$ with annual signal removed showing wavelike travel curves. Swesty followed the sla high for $\sim 500$ days from point A $\left(25^{\circ} \mathrm{W}\right)$ to B $\left(41^{\circ} \mathrm{W}\right)$ covering a distance of $\sim 1650 \mathrm{~km}$ at a mean speed of $3.8 \mathrm{~cm} \mathrm{~s}^{-1}$. The track of RRS 'Charles Darwin', CD83 (dashed), in December 1993 from $16^{\circ} \mathrm{W}$ to $34^{\circ} \mathrm{W}$ ( $\left.\sim 1700 \mathrm{~km}\right)$ cuts the positive sla travel curves (dashed) 1 and 2 at $26^{\circ} \mathrm{W}$ and $21^{\circ} \mathrm{W}$ (see Figure 2). The track cuts the reference travel line 0 or AB at $33^{\circ} \mathrm{W}$ (square) where Swesty was discovered. Figure 5. Summary diagram of westward propagating disturbances at $32.5^{\circ} \mathrm{N}$ seen by altimeter, from $10^{\circ} \mathrm{W}$ to $40^{\circ} \mathrm{W}$ over an 8 -y period (Julian Days, JD) with year given. The altimeter signal is the $s l a(\mathrm{~mm})$ with the annual signal removed. The mean period in the west of the region is $\sim 200$ days and the wavelength is $\sim 540 \mathrm{~km}$ giving an average westward travel speed of $\sim 3.1 \mathrm{~cm} \mathrm{~s}^{-1}$. Negative sla travel curves are denoted by $0,1,2,3,4,5,6$ and 7 , covering a 1400 day study period from 1995 to 2000. Drogued buoys and ALACE floats tracked (dotted) westward along the negative sla travel curve of Storm 0 from $33.6^{\circ} \mathrm{W}$ to $40.3^{\circ} \mathrm{W}$ with westward speed of $2.7 \mathrm{~cm} \mathrm{~s}^{-1}$ over a period of 270 days. Storm 0 has an origin near $25^{\circ} \mathrm{W}$ (marked with large ' 0 ') near JD 16400. Storm 0 was surveyed by RRS 'Charles Darwin' (CD 97, October 1995) near 33.5 W, JD 16735 (open square) when it would have been about 325 days old and later intercepted by HMS 'Hecla' (dashed line marked H) on JD 16955 near $40^{\circ} \mathrm{W} \sim 550$ days after its first noted position ' 0 '. Dashed line marked 155 is the 2 year current meter and thermistor chain data line for Rig 155 deployed on CD97. L is Storm Leticia surveyed by BIO 'Hesperides' in April 1999 shown as open square. Sla track of L over a period of 1 year is shown dotted with circles at start and end positions. ALACE 25973 was also deployed in the open square at $32.5^{\circ} \mathrm{N}, 33.3^{\circ} \mathrm{W}$ (see Figure 6 for the position $\sim 7$ years later). 


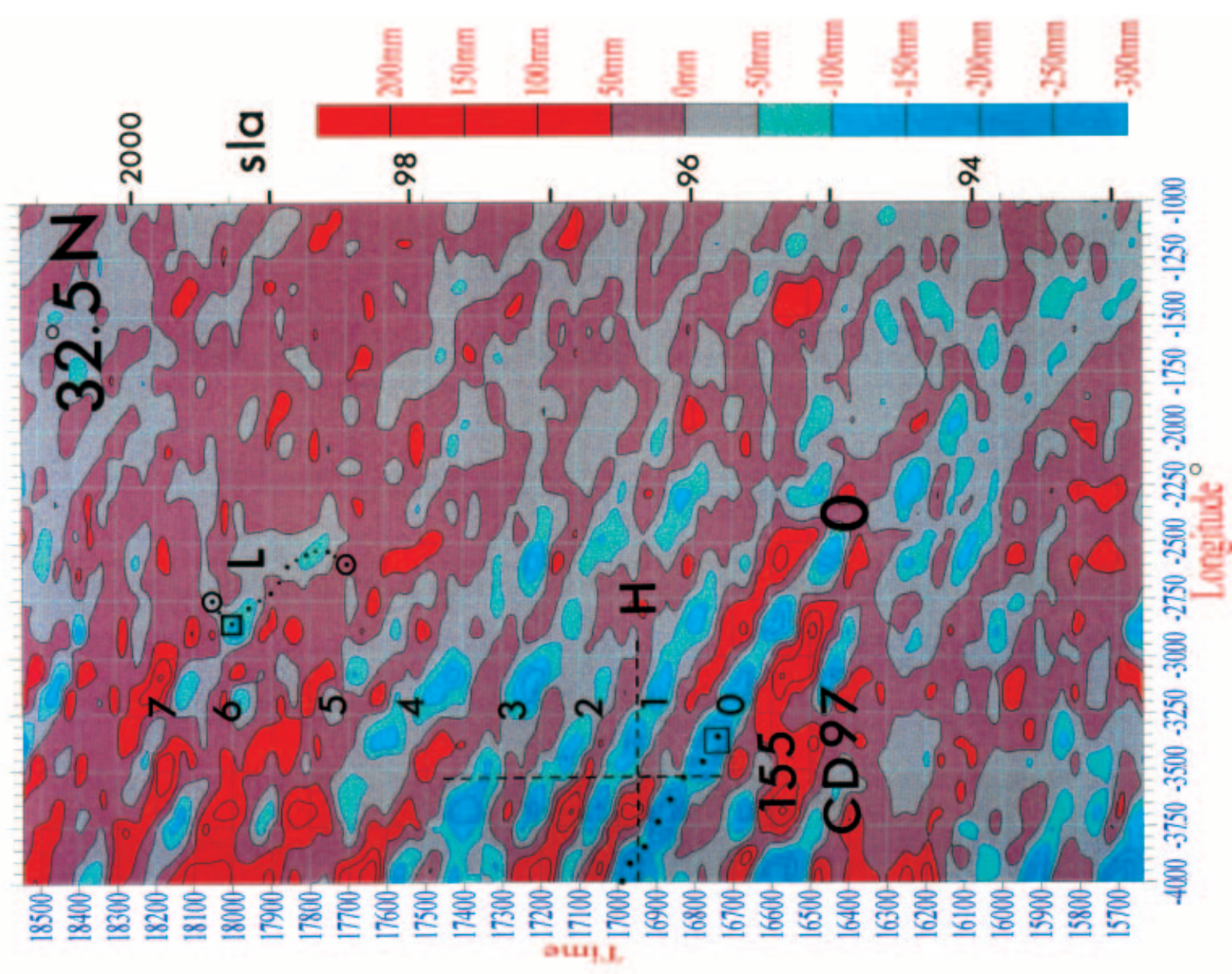

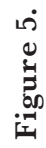

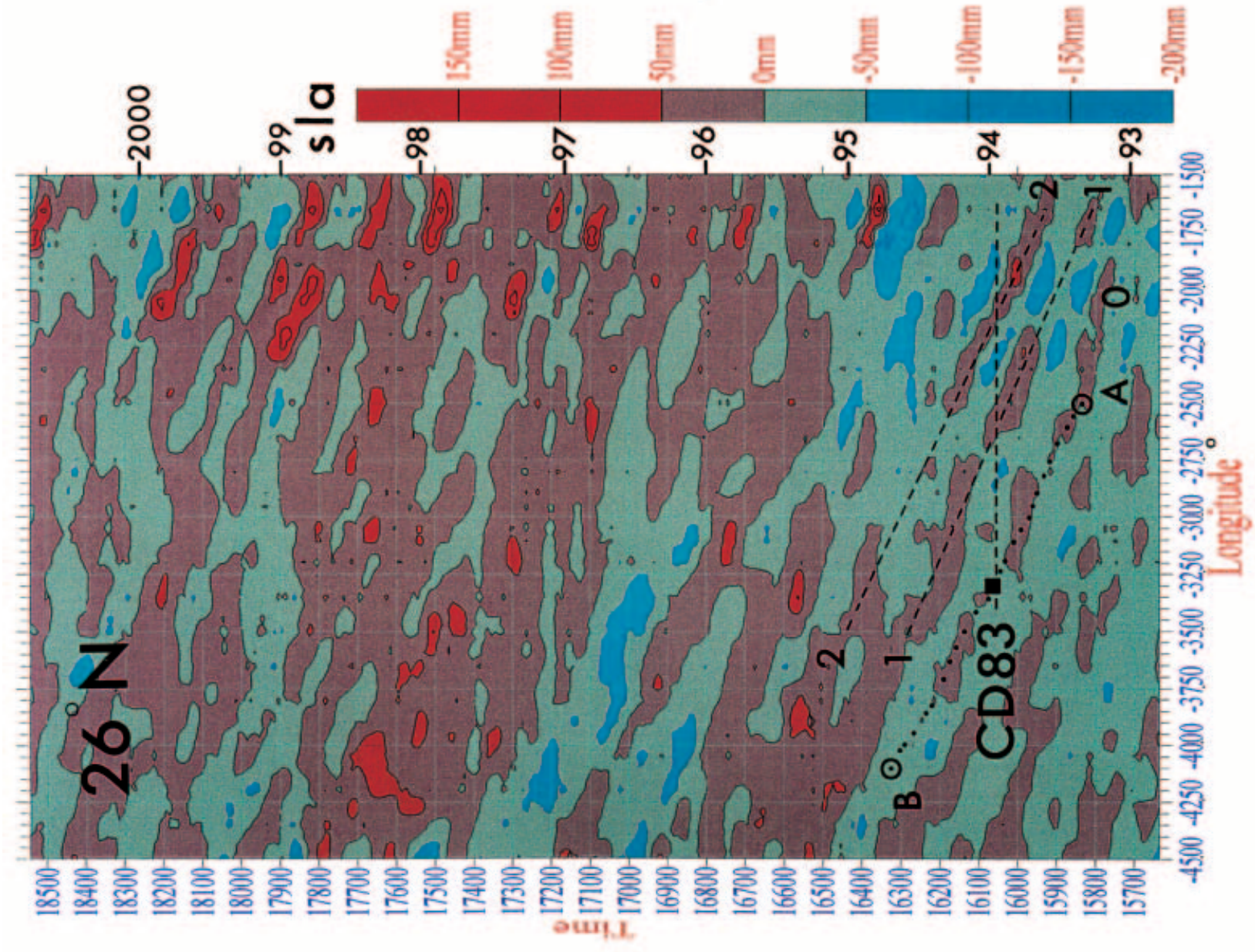


A

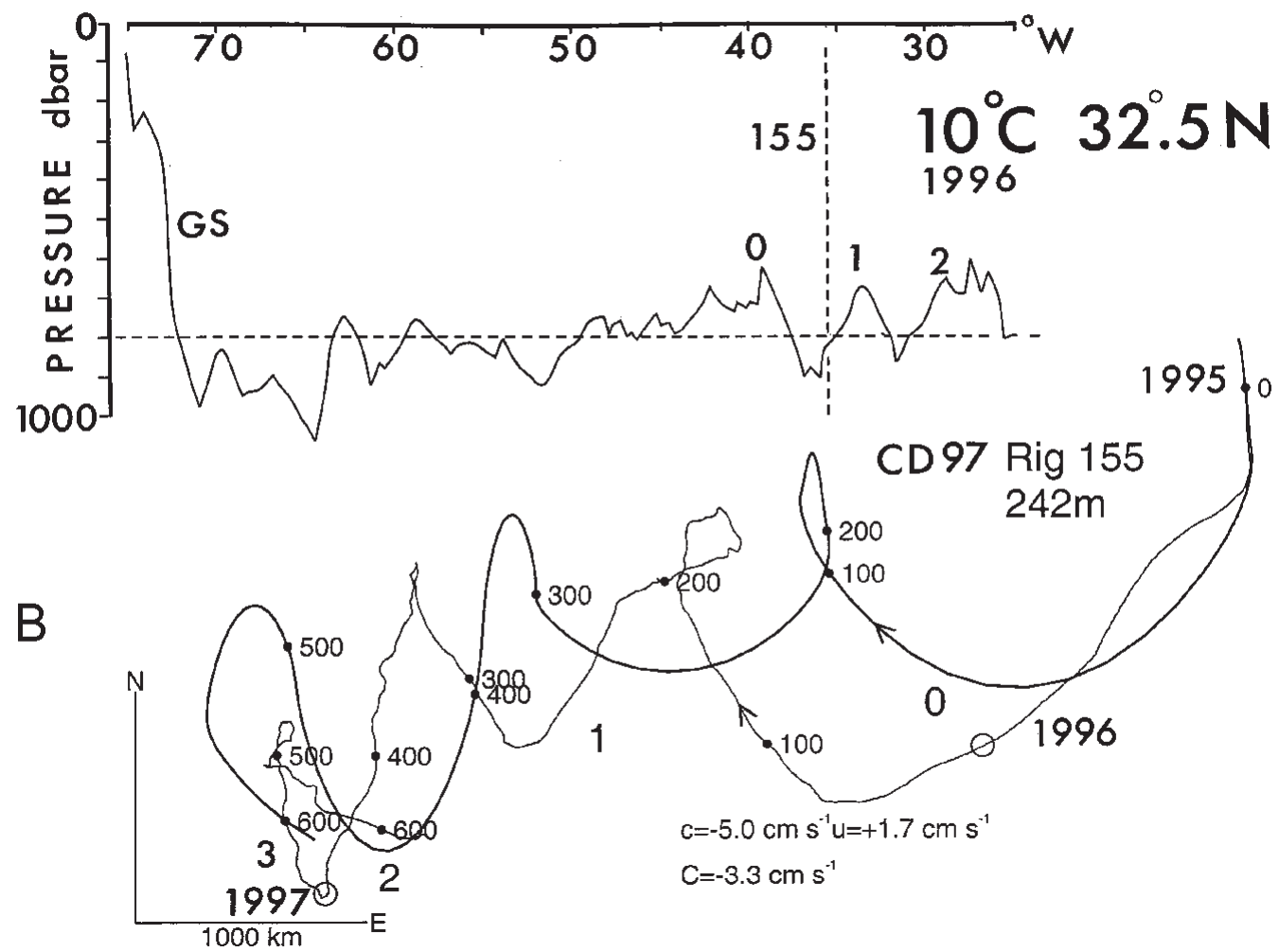

Figure 4. (A) Depth (pressure in dbar) of the $10^{\circ} \mathrm{C}$ isotherm against longitude at $\sim 32.5^{\circ} \mathrm{N}$ in June 1996 (HMS 'Hecla', see Figure 1 for section from America) from $\sim 150$ profiles of calibrated temperature (T5s and CTDs). GS represents the position of the Gulf Stream; horizontal dashed line is at 800 dbar. Vertical dashed line is the position of Rig 155 at $35.5^{\circ} \mathrm{W}, 32.5^{\circ} \mathrm{N}$. Storm 0 (SO), indicated by ' 0 ', moving west has passed the rig and storms 1 and 2 marked ' 1 ' and ' 2 ' have yet to arrive. (B) Measurements (thin line) and simulated PVD $\left(5 \mathrm{~cm} \mathrm{~s}^{-1}\right.$ west phase speed for eddies and a mean flow field of $1.7 \mathrm{~cm} \mathrm{~s}^{-1}$ eastward) for current meter record at $242 \mathrm{~m}$ depth on Rig 155. Annotations are every 100 days from the start of the record (28.10.95). 0,1,2, (with centres passing to the south of the rig) and 3 indicate four cyclonic Storm eddies passing the rig; eddy labelled ' 3 ' has not fully passed the rig to the north. $1000 \mathrm{~km}$ scale shown.

eddy had an aspect ratio $\sim 0.1 \%$, comparable with Storms but is an order of magnitude flatter than a Meddy.

\section{CD83 CTD/XBT section at $26^{\circ} \mathrm{N}$}

The $\sim 1700 \mathrm{~km}$ CTD $/ \mathrm{XBT}$ section at $26^{\circ} \mathrm{N}$ obtained from RRS 'Charles Darwin' in December 1993 (CD83) shows the thickening of isotherms in the temperature range $19-20^{\circ} \mathrm{C}$ at $33^{\circ} \mathrm{W}$ where Swesty was discovered
(Figure 2). There is also ocean structure near $26^{\circ} \mathrm{W}$ and 21-22 W. Swesty was surveyed with CTDs and SeaSoar and drogued buoys were deployed. In all, Swesty was followed continuously by drogued buoys (3346, 1811, 3915, 3919) for 505 days (Table 1) and in this time covered a zonal distance of $1650 \mathrm{~km}$ at a latitude near $\sim 25.5^{\circ} \mathrm{N}$ giving a westward speed of $3.3 \mathrm{~km} \mathrm{~d}^{-1}$ or $3.8 \mathrm{~cm} \mathrm{~s}^{-1}$. Swesty might have been formed south-west of the Canary Islands

Table 2. Eulerian residual currents from Iberian slope and ocean current meter deployments.

\begin{tabular}{|c|c|c|c|c|c|c|c|c|}
\hline $\begin{array}{l}\text { Mooring } \\
\text { latitude } \\
\text { longitude }\end{array}$ & $\begin{array}{c}\text { Water } \\
\text { depth } \\
(\mathrm{m})\end{array}$ & $\begin{array}{c}\text { Current } \\
\text { meter } \\
\text { number }\end{array}$ & $\begin{array}{c}\text { Current } \\
\text { meter } \\
\text { depth }(\mathrm{m})\end{array}$ & $\begin{array}{l}\text { Start } \\
\text { date } \\
\text { d.m.y }\end{array}$ & $\begin{array}{l}\text { Record } \\
\text { length } \\
\text { (days) }\end{array}$ & $\begin{array}{l}\text { Speed } \\
\mathrm{cm} \mathrm{s}^{-1}\end{array}$ & $\begin{array}{c}\text { Direction } \\
{ }^{\circ} \mathrm{T}\end{array}$ & $\begin{array}{c}\text { Data } \\
\text { source }\end{array}$ \\
\hline $\begin{array}{c}149 \\
36^{\circ} 49.1^{\prime} \mathrm{N} \\
09^{\circ} 30.3^{\prime} \mathrm{W}\end{array}$ & 1506 & 4435 & 480 & 01.01 .94 & $713(420)$ & 8.0 & 320 & Pingree \\
\hline $\begin{array}{c}152 \\
36^{\circ} 29.9^{\prime} \mathrm{N} \\
12^{\circ} 17.6^{\prime} \mathrm{W}\end{array}$ & 3370 & $\begin{array}{l}2068 \\
3115 \\
4436\end{array}$ & $\begin{array}{r}366 \\
812 \\
1313\end{array}$ & $\begin{array}{l}31.12 .93 \\
31.12 .93 \\
07.01 .94\end{array}$ & $\begin{array}{l}711(487) \\
711 \\
85\end{array}$ & $\begin{array}{l}4.9 \\
3.6 \\
6.9\end{array}$ & $\begin{array}{l}222 \\
203 \\
227\end{array}$ & Pingree \\
\hline $\begin{array}{c}155 \\
32^{\circ} 31.2^{\prime} \mathrm{N} \\
35^{\circ} 29.1^{\prime} \mathrm{W}\end{array}$ & 3910 & $\begin{array}{r}11214 \\
7948 \\
11215\end{array}$ & $\begin{array}{r}242 \\
742 \\
1368\end{array}$ & $\begin{array}{l}28.10 .95 \\
28.10 .95 \\
18.12 .95\end{array}$ & $\begin{array}{l}607 \\
735 \\
602\end{array}$ & $\begin{array}{l}7.7 \\
2.5 \\
2.6\end{array}$ & $\begin{array}{l}242 \\
279 \\
273\end{array}$ & Pingree \\
\hline
\end{tabular}


in the winter of $1992 / 1993$. If this was the case, winter mixing meant that Swesty's core was exposed to the atmosphere in the winter of 1992/1993 but not in the winter of $1993 / 1994$ as the eddy core subducted westward with a measured $2^{\circ} \mathrm{C}$ mixed layer cap in December 1993 (Figure 2). The southward transport for the December 1993 CTD section $20^{\circ} \mathrm{W}-34^{\circ} \mathrm{W}$ was $16.4 \mathrm{~Sv}$ with a 2000 dbar reference level.

\section{Wave and eddy travel curves at $26^{\circ} \mathrm{N}$}

Although the annual signal is usually dominant in the sla time structure at a point and westward longwave propagating structure with annual period may be important, especially in upwelling (Hagen, 1986) and equatorial regions, shorter westward propagating sla structures can be masked by including the annual harmonic, which largely relates to the annual heating cycle, so Fourier analysis and filtering has been used to remove the annual cycle. The sla contoured structure at $26^{\circ} \mathrm{N}$ (Figure 3) against longitude and time in JDs shows travel lines or fixed contours moving westward with speeds of typically $4 \mathrm{~cm} \mathrm{~s}^{-1}$. These sla patterns are believed to result from a combination of eddies and waves. A Fourier analysis showed that the temporal separation of the travel curves was near semi-annual but that other blue-shifted frequencies could be significant. Either by eye or Fourier analysis a separation of $\sim 160-180$ days is obtained. Interpolating the sla structure (see for example dashed curves in Figure 3) gives a mean westward speed of $\sim 4.0 \mathrm{~cm} \mathrm{~s}^{-1}$ for the propagating structure. This gives a mean wavelength or separation between repeating structure of $\sim 550 \mathrm{~km}$. Plotting the position and time of Swesty from the start of its $1650 \mathrm{~km}$ journey through to the December survey position where more Argos buoys were deployed and then on to the estimated position of the eddy centre as the last drogued buoy left the eddy $\sim 500$ days later shows clearly that a positive sla travel curve has been followed (Figure 3). Swesty's progress appeared marginally slower $\left(3.8 \mathrm{~cm} \mathrm{~s}^{-1}\right.$, Table 1$)$. This might result from a number of factors. An eddy which is travelling westward by phase propagation would leave the buoy behind if the buoy radius became too large. Swesties may travel marginally slower than waves. We note that there are also climate changes in the sla record. The sla was marginally elevated in 19961998 with respect to mean conditions. These longterm changes in sea level relate to climate or circulation changes in the Subtropical Gyre (see later).

The broad summary for conditions at $26^{\circ} \mathrm{N}$ is that eddies and waves travel at much the same westward speed and that the altimeter although measuring surface height properties is revealing internal ocean structure. Structure was evident in the zonal temperature section at $33^{\circ} \mathrm{W}$, $26^{\circ} \mathrm{W}$ and $21.5^{\circ} \mathrm{W}$ which matched the spatial separation of the positive sla travel curves. At this latitude in the Eastern Basin, the mean stability increases from deep to shallower levels with a maximum Brunt-Vaisala Frequency, N, located in the seasonal thermocline or base of the mixed layer in winter. The altimeter is seeing the geostrophic surface current response to the displacement of the isotherms (or isopycnals) in the upper part of the water column. Here, we have described anticyclonic structure but the negative sla travel curves cut the ship's track at $23^{\circ} \mathrm{W}$ and $27-28^{\circ} \mathrm{W}$ and these sla structures appear dome-like in the CTD/XBT section of the thermocline (Figure 2). In the next section, a convincing case is made showing that negative sla data correlate with dome-like or cyclonic in situ measurements.

\section{Waves and eddies at $30-34^{\circ} \mathcal{N}$ (Storm)}

A STORM is a SubTropical Ocean Ring of Magnitude. Storms are cyclonic eddies moving westward through subtropical water with a component of more northern water in the upper water column and therefore tend to be south of the Azores Current near $34^{\circ} \mathrm{N}$ in the Eastern Basin which can act as a barrier to ventilation (New et al., 2001). This means they are characterized by excess oxygen concentration near the sea surface $(<500 \mathrm{~m}$ depth but below the mixed layer) and deficient in subtropical water near a temperature of $17-18.5^{\circ} \mathrm{C}$ when newly formed. These characteristics may still be evident 300 days after formation. The water deficit means that Storms will always be cyclonic. The eddy size or current structure influence can extend across a diameter or axis of $350 \mathrm{~km}$, though the structure itself is often quite elliptical $(\sim 0.6$ axis ratio, or ellipticity). The aspect ratio for the structure is typically $0.1 \%$. Near $30-35^{\circ} \mathrm{N}$, there are also related anticyclonic eddies which have an upper water column of Subtropical Water. Both types of eddies have been extensively studied (Pingree et al., 1996; Pingree \& Sinha, 2001; Mouriño et al., 2002) and the westward movement of these eddies from $\sim 25^{\circ}-45^{\circ} \mathrm{W}$ and related wave structure is the main concern of this section. Eleven drogued Argos buoys and five ALACE subsurface floats deployed in the same eddy showed that Storms could be followed in a Lagrangian sense as some kind of entity for as long as 300 days. Core diffusion values of $2 \times 10^{2} \mathrm{~m}^{2} \mathrm{~s}^{-1}$ were determined, a value $\sim 100$ times larger than that measured for a Biscay Swoddy core (Pingree \& Le Cann, 1992). The mean west travel speed for the first Storm surveyed, the reference or Storm 0, abbreviated to $S 0$, was $\sim 2.8 \mathrm{~cm} \mathrm{~s}^{-1}$ over a $\sim 303$-d period (Table 1).

Rig 155, two years at $32.5^{\circ} \mathcal{N}$ in the Subtropical Front: SO, S1, S2, S3

Current meter moorings 155 and 156 provided records of isotherm displacements and currents over a 2-y period and in Pingree \& Sinha (2001) it was shown that Storms travelled westward by advection and phase propagation but that phase propagation exceeded advection. The mean near surface current at $242 \mathrm{~m}$ was $8 \mathrm{~cm} \mathrm{~s}^{-1}$ southwestward ( $\sim 607$ day average, Table 2$)$ at Rig 155 but numerical simulations showed that this value was largely due to the signatures of eddies in the current meter record and that the eddies were travelling westward by phase propagation on a mean Eulerian flow field that was near zero or weakly eastward (Figure 4B). It was also found that warm water $\left(\sim 18^{\circ} \mathrm{C}\right)$ was moving or flowing eastward $\left(\sim 4 \mathrm{~cm} \mathrm{~s}^{-1}\right.$ at $242 \mathrm{~m}$ depth$)$ and that cooler water (cyclonic eddies) was moving westward $\left(\sim-4 \mathrm{~cm} \mathrm{~s}^{-1}\right.$ at $242 \mathrm{~m}$ depth), representing shear conditions across the Subtropical Front. Even if an eddy travels entirely by phase propagation water can remain trapped and move with the pattern speed (Flierl, 1981). It was shown there was a semi-annual periodicity associated with the regularly repeating structure arriving at the two moorings. So Storm eddies have wavelike properties. 


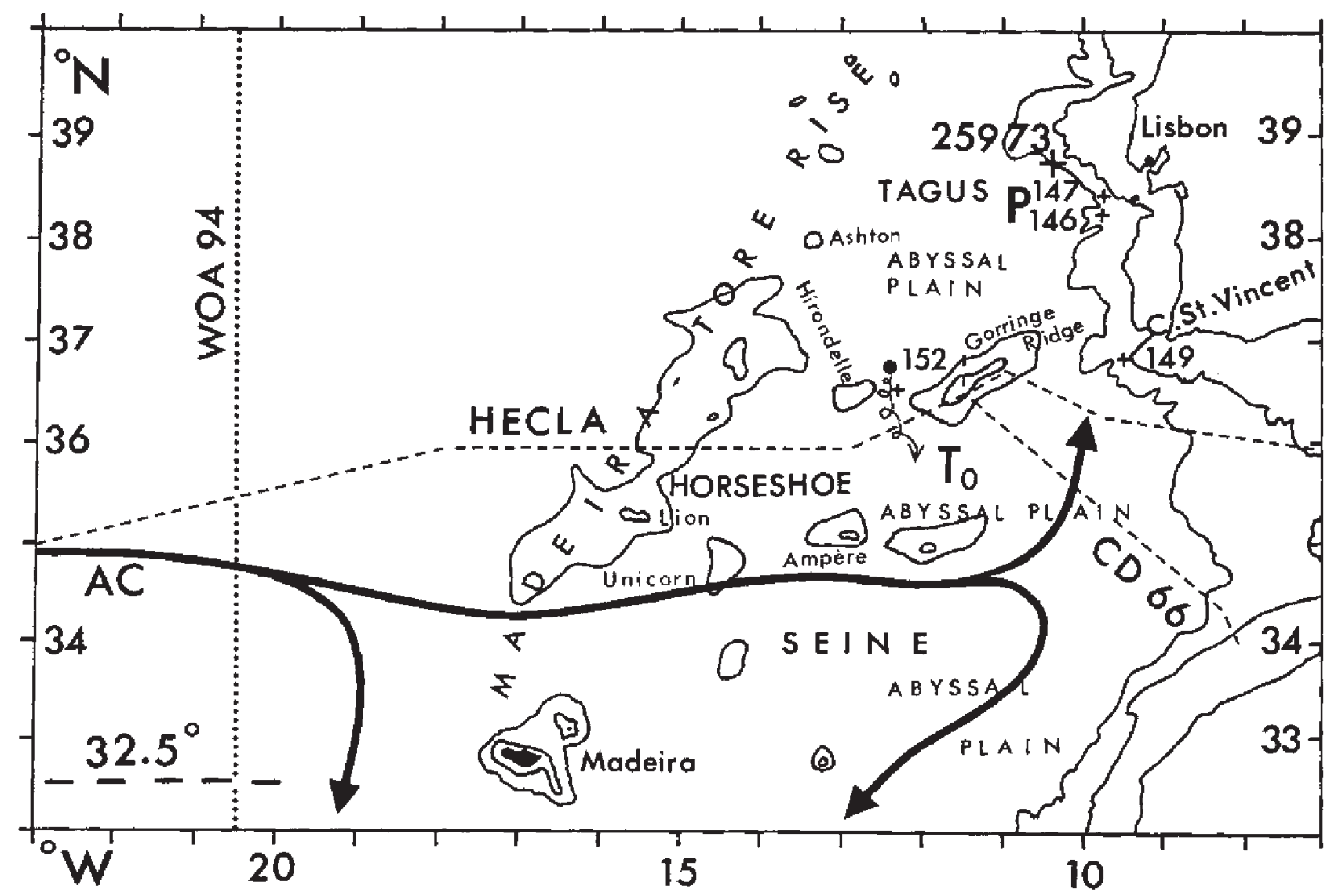

Figure 6. Map showing place names used in the text. AC is a 1992-1993 mean position for the Azores Current, separating eddy and wave conditions at $\sim 32.5^{\circ} \mathrm{N}$ from the Meddy region considered near $\sim 36^{\circ} \mathrm{N}$. T0 is Smeddy Tagus, moving through the gap between the Tagus Abyssal Plain and the Horseshoe Abyssal Plain in April 1992. Cross is the position of Rig 152 deployed in the gap between Gorringe Ridge and Hirondelle Seamount on 31 December 1993. Position of Rigs 146, 147 and 149 shown. Rigs 146 and 147 were deployed in Meddy Pinball $(\mathrm{P})$ which was leaving the continental slope at the time of deployment from RRS 'Charles Darwin' (CD 97) in January 1994. Two drogued Argos buoys, 2 ALACE subsurface floats and 2 RAFOS floats were also deployed in Meddy Pinball from RRS 'Charles Darwin' (see Figure 11; Table 1). CD66, Hecla and WOA94 sections indicated. Cross marked 25973 is the position of ALACE 25973 on 19 May 2002. This subsurface float was deployed in Storm 0 on 24 October 1995 (see Figure 5). Water depth contours are $1000 \mathrm{~m}$ and $3000 \mathrm{~m}$.

Wave and eddy travel curves at $32.5^{\circ} \mathrm{N}$

The results of the Storm studies are summarized on the sla plot for westward propagating disturbances at $32.5^{\circ} \mathrm{N}$ (Figure 5). Storm O (surveyed in October 1995) and followed by Lagrangian methods (for $\sim 300$ days) has a travel curve that is not distinguishable from the negative sla line which can be extrapolated back to a position (marked 0) near $24.5^{\circ} \mathrm{W}$ in November/December 1994 , almost a year before the RRS 'Charles Darwin' CD97 survey. This travel curve is the reference travel curve or line 0 and is associated with domed isotherms (c.f. Figure 3). Pingree et al. (2002) showed that temperature measurements in the permanent thermocline at the position of Rig 155 correlated with the sla data such that

Depth of $10.0^{\circ} \mathrm{C}$ isotherm $(\mathrm{m})=$

$$
631 \operatorname{sla}(\mathrm{m})+788 \mathrm{~m}
$$

with a correlation coefficient squared value of $r^{2}=0.6$ and this relationship is valid for both cyclonic and anticyclonic eddies or wavelike structure at this location. The maximum correlation coefficient between isotherm displacement and sla occurred in the permanent thermocline where the correlation coefficient reached a value of $r=0.8$, at a depth of $500 \mathrm{~m}$. The highest correlation between sla or rather sla gradient occurs with in situ ocean current measurement. At $242 \mathrm{~m}$ depth, the correlation coefficient for the current data of Figure $4 \mathrm{~B}$ was $r=0.9$.

The overall results showed that the magnification of surface displacement to internal displacement, $\mathrm{B} \sim 631$, in equation (1), was approximately constant with depth and that therefore the structure of velocity and potential density, $\rho$, were similar with depth (below the seasonal thermocline) and that $\mathrm{B} \sim \rho / \delta \rho \sim 700$ where $\delta \rho$ is the potential density difference between the near surface $(\sim 200 \mathrm{~m})$ and bottom. The resulting structure functions for current and displacement are not those that would be expected for a plane Rossby Wave mode.

Although further measurements are required, there is no reason to believe that the magnification value will not be approximately valid for climate changes in this region. Figure $4 \mathrm{~A}$ shows the slope of the $10^{\circ} \mathrm{C}$ isotherm as about $240 \mathrm{~m}$ over an interval of $40^{\circ}$ of longitude. A corresponding 


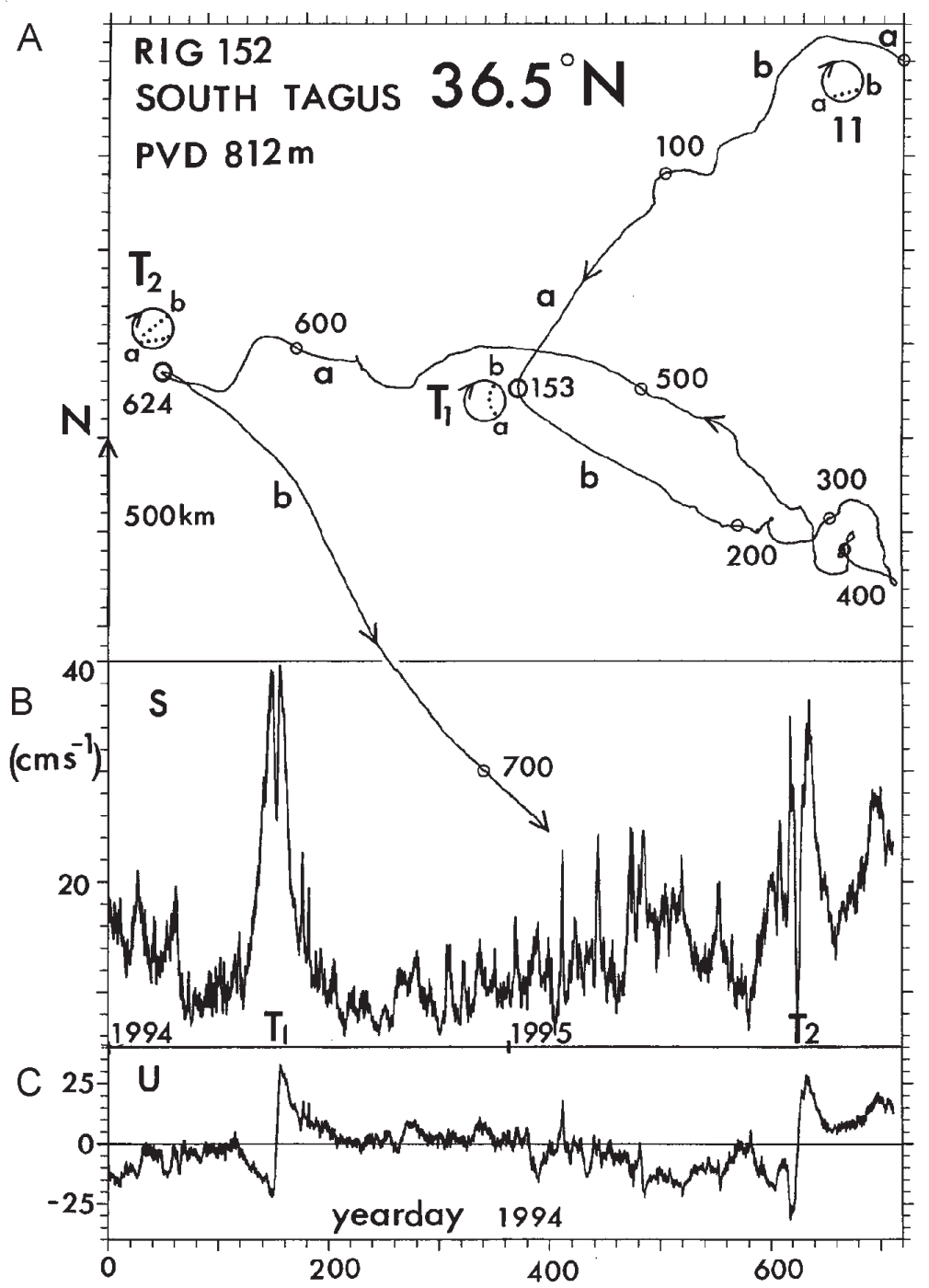

Figure 7. (A) Progressive vector diagram (PVD) for Rig 152 (current meter 3115 at $812 \mathrm{~m}$ ) at $36.5^{\circ} \mathrm{N}, 12.3^{\circ} \mathrm{W}$ annotated every 100 days (yearday 1994). Meddies 11, T1 and T2 marked. A dotted track within a circle of $\sim 100 \mathrm{~km}$ diameter with labels $a$ and $b$ shows the way the Meddy was cut by the mooring. It is clear that a Meddy has a spatial influence on the PVD (and hence the estimated residual current) an order of magnitude greater than its size. $500 \mathrm{~km}$ scale shown. (B) Speed (S, with $24 \mathrm{~h}$ averaging, $\mathrm{cm} \mathrm{s}^{-1}$ ) against yearday 1994. (C) East component of current (U, $24 \mathrm{~h}$ averaging, $\left.\mathrm{cm} \mathrm{s}^{-1}\right)$. Note there are only two marked events in the 711 day record. The east component (U) swings from west to east as the Meddy passes south and the speed (S) falls to a minimum as the Meddy centre makes its nearest approach. These two times of $\mathrm{U}=0$ were at YD153 and YD624 and are marked on the PVD (see A).

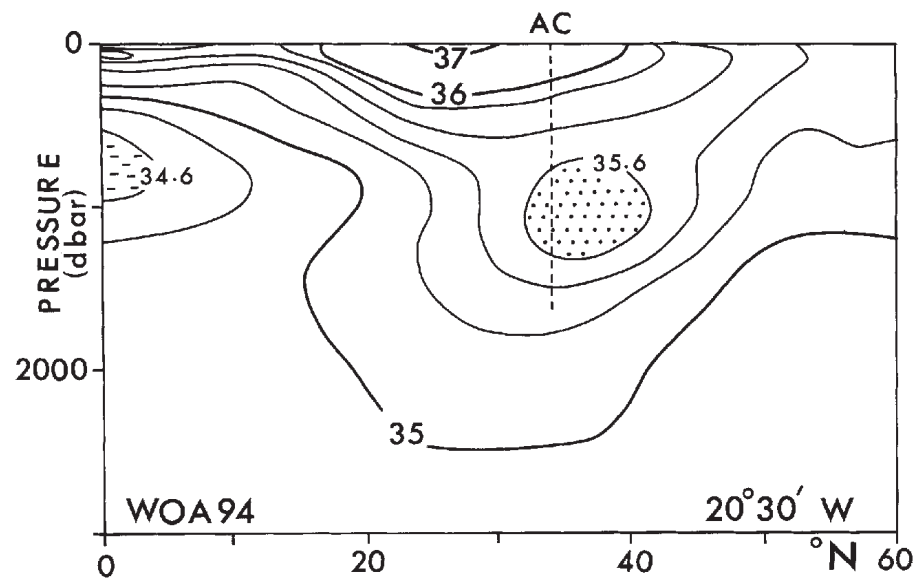

Figure 8. WOA94 salinity (psu) section from $0-60^{\circ} \mathrm{N}$ at $20.5^{\circ} \mathrm{W}$ showing Mediterranean Water with salty core at $>35.6 \mathrm{psu}$ (shaded) with centre near $36-37^{\circ} \mathrm{N}, 1100 \mathrm{dbar}$, and Antarctic Intermediate Water minimum ( $<34.6 \mathrm{psu}$ ). Azores Current (AC) restricting the southward flow of salty Mediterranean Water is represented by a dashed line near $34^{\circ} \mathrm{W}$. 


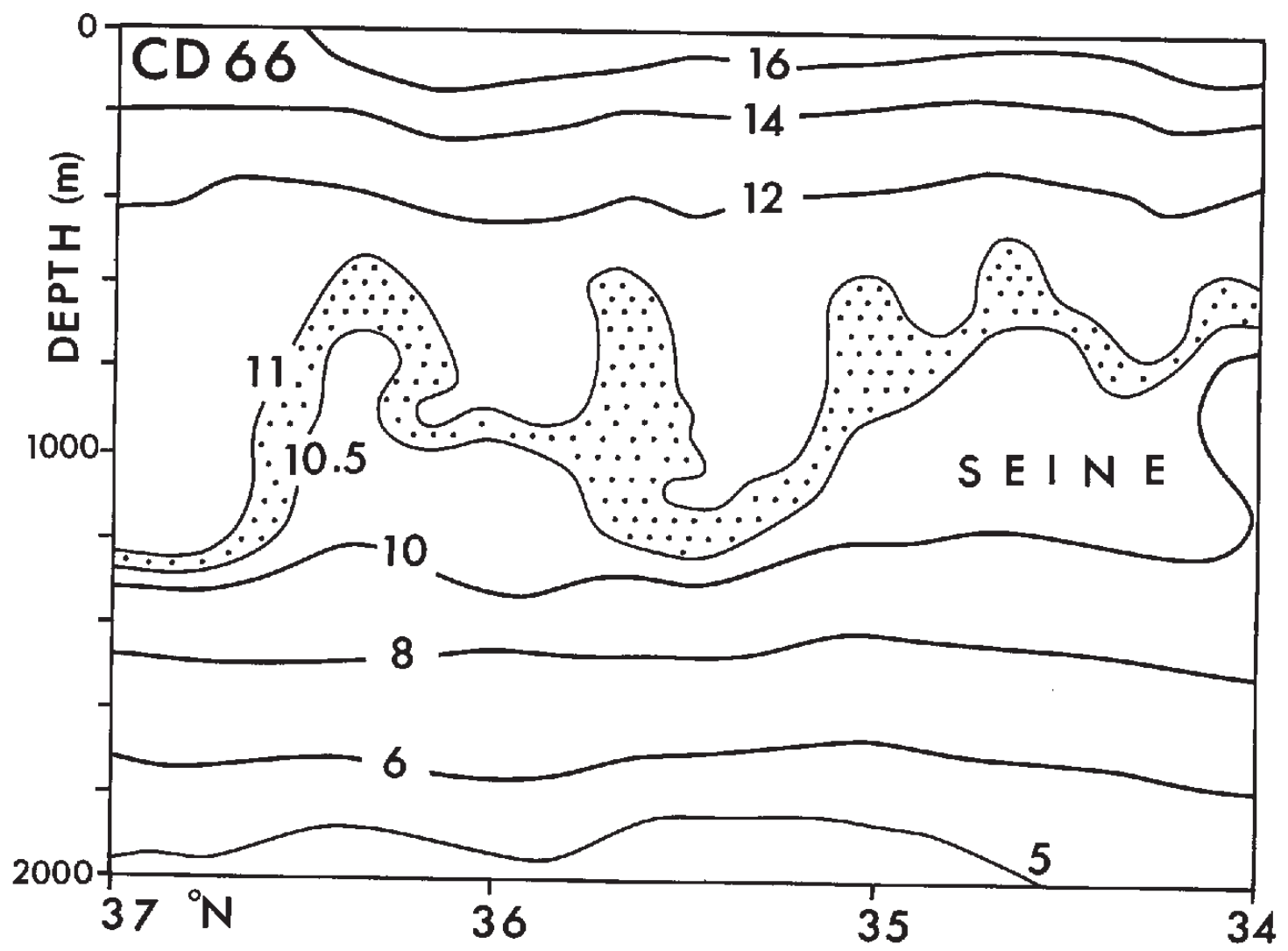

Figure 9. CD66 XBT/CTD temperature $\left({ }^{\circ} \mathrm{C}\right)$ section from $34^{\circ} \mathrm{N}$ to $37^{\circ} \mathrm{N}$ cutting through the Seine Abyssal Plain (denoted by SEINE) and Horseshoe Abyssal Plain in March 1992 showing increasing influence of Mediterranean Water north of $35^{\circ} \mathrm{N}$. The $10.5-11^{\circ} \mathrm{C}$ isotherm band (shaded) descends to the north and the thickness of water in the temperature range $11-12^{\circ} \mathrm{C}$ increases. The $10^{\circ} \mathrm{C}$ and $12^{\circ} \mathrm{C}$ isotherms are relatively level and separated by $\sim 850 \mathrm{dbar}$ except on the Moroccan continental slope near $34^{\circ} \mathrm{N}$, which is cold and fresh due to poleward flow.

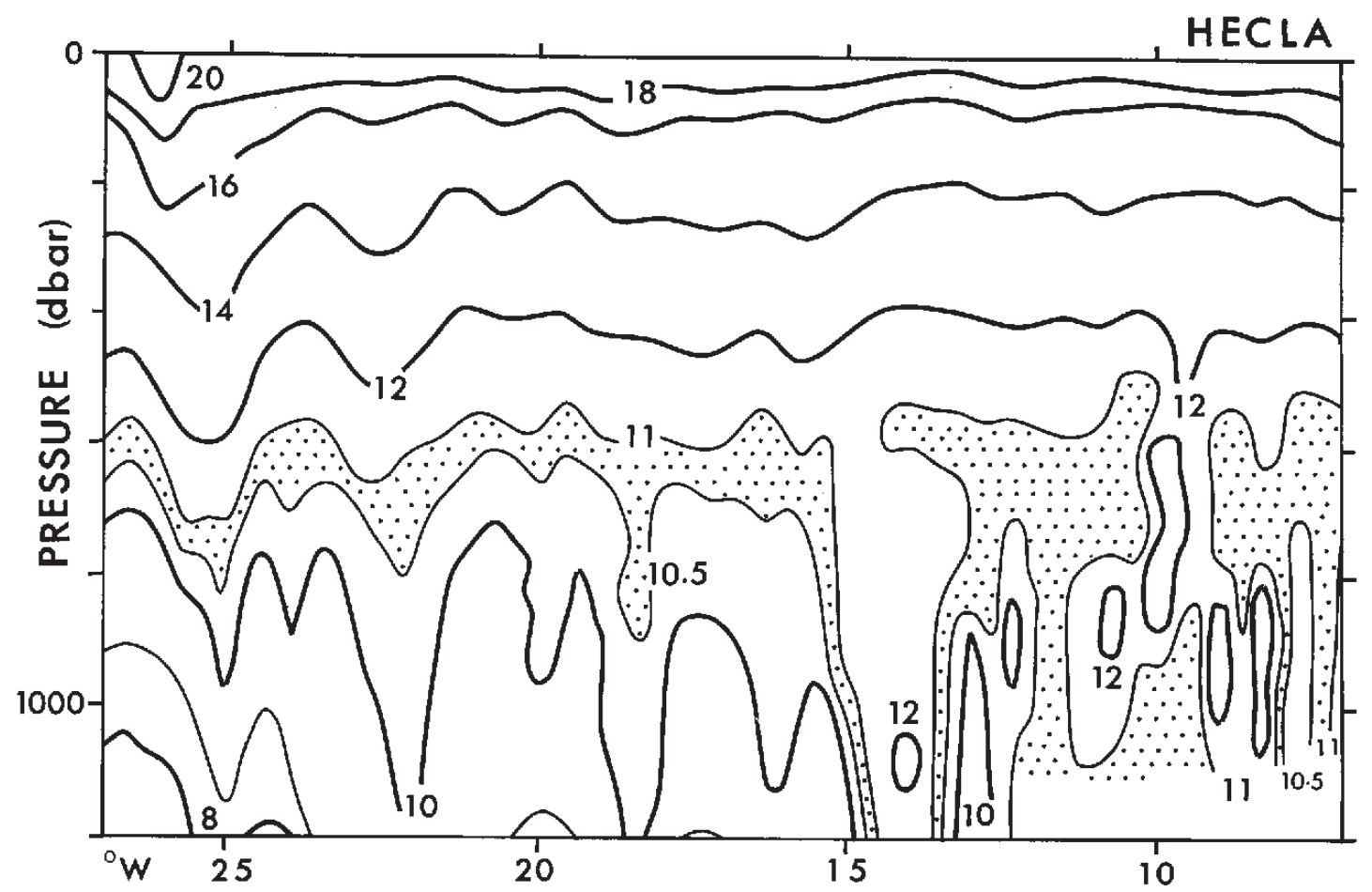

Figure 10. HMS 'Hecla' XBT temperature $\left({ }^{\circ} \mathrm{C}\right)$ section obtained in June 1996 using 61 T5 profiles from $27^{\circ} \mathrm{W}\left(\sim 34^{\circ} \mathrm{N}\right)$ to $7^{\circ} \mathrm{W}$ $\left(\sim 36^{\circ} \mathrm{N}\right)$ passing through the Horseshoe Abyssal Plain (Figure 6). Contours are every two degrees with additional contours (thin lines at $11^{\circ} \mathrm{C}, 10.5^{\circ} \mathrm{C}$ and $9^{\circ} \mathrm{C}$ ). The Mediterranean Water influence (or thickening of the $10-12^{\circ} \mathrm{C}$ isotherm band) occurs near $26^{\circ} \mathrm{W}$ with shading between $10.5-11^{\circ} \mathrm{C}$. 


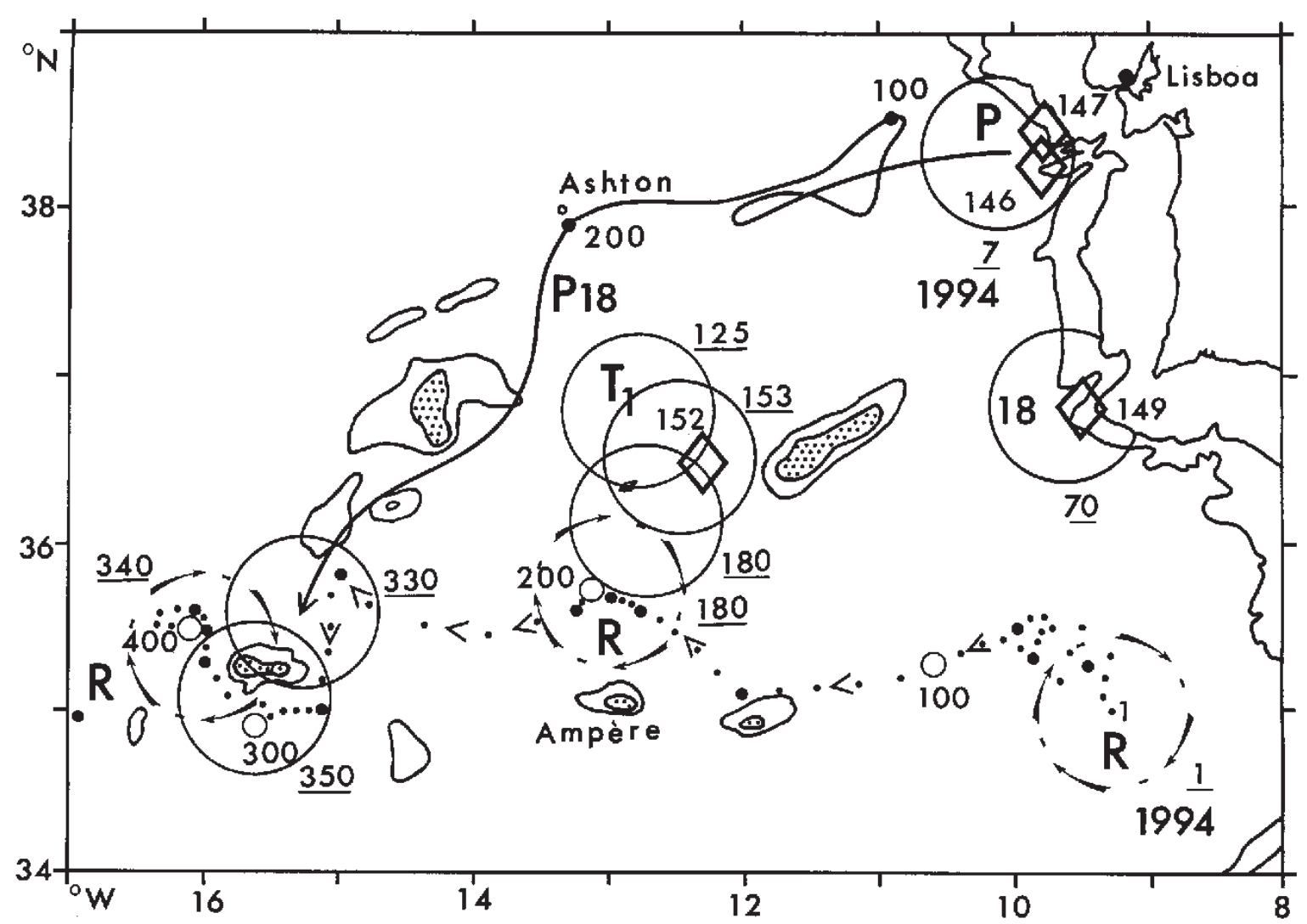

Figure 11. Westward track of positive sla or Meddy R near $35.5^{\circ} \mathrm{N}$ from 1 January 1994 (YD1) to 1 March 1995 (YD425) from $\sim 9^{\circ} \mathrm{W}$ through the Horseshoe Abyssal Plain to Lion Seamount. A scale of influence for $\mathrm{R}$ is indicated by anticyclonic arrows forming a $100 \mathrm{~km}$ diameter circle. The underlined number next to the circle is the 1994 yearday for this position. The track of a central position of $\mathrm{R}$ is shown dotted (and with arrow heads) with circles annotated every 100 days (yearday 1994, YD); bold dots are at 25 day intervals. Current meter mooring positions 146, 147, 149, 152 are shown as open diamonds. South of the gap between Gorringe Ridge and Hirondelle Seamount, R merged with T1. T1 (100 km diameter circle) is shown at three positions in time, YD125, YD153 (see Figure 7) and YD180; R is shown with arrows for YD180. Pinball, P, leaves the continental slope near YD7. Meddy 18 is near Rig 149 in March 1994 (YD70). The track of Pinball is shown as a continuous line annotated at YD100 and YD200. P becomes P18 near YD217 (see text). R (or RT1) continues west reaching the west side of Lion Seamount near the time P18 arrives from the north. The arrowhead at the end of Pinball's track shows the central position of P18 for YD330 with $100 \mathrm{~km}$ diameter circles for YD330 and YD350. $\mathrm{R}$ is shown for YD340. The sla anomaly R (or RT1P18) appeared fairly stationary west of Lion Seamount from YD325-410. Water depth contours $1000 \mathrm{~m}$ and $2000 \mathrm{~m}$ shown $(<1000 \mathrm{~m}$ on seamounts shaded).

dynamic height difference (HMS 'Hecla' CTDs 7017 at $\sim 60^{\circ} \mathrm{W}$ and 7025 at $20^{\circ} \mathrm{W}$ ) was 38.1 dyn.cm (equal to $38.9 \mathrm{~cm}$ ) giving $\mathrm{B} \sim 600$ for large scale ocean climate structure where the annual mean zonal wind stress is near zero.

Fourier analysis of the sla structure at $32.5^{\circ} \mathrm{N}$ gave values in agreement with those already determined from the current meter data analysis. Namely that the separation of the travel curves was near semi-annual but red-shifted in frequency with a mean repeating period of $\sim 200$ days. The mean west travel speed for the sla structure was $\sim 3.1 \mathrm{~cm} \mathrm{~s}^{-1}$ marginally higher than that measured for Storm $0 \sim 2.8 \mathrm{~cm} \mathrm{~s}^{-1}$ but buoys and floats ultimately leave an eddy and therefore an estimate based on the longest Lagrangian track tends to be biased low. Westward eddy/sla speeds are higher $\left(\sim 5.0 \mathrm{~cm} \mathrm{~s}^{-1}\right)$ west of the Mid-Atlantic Ridge (near $\left.40^{\circ} \mathrm{W}\right)$ in the Western Basin and slower to the east of $25^{\circ} \mathrm{W}\left(2.4 \mathrm{~cm} \mathrm{~s}^{-1}\right)$.

The four eddy or wavelike Storm features called S0, S1, S2, S3 measured at Rig 155 position (Figure 4B) were readily identifiable in the sla structure on the negative travel curves $0,1,2$ and 3 as were S0 and S1, when S0 was surveyed a second time from HMS 'Hecla' (Figure 5). In a further sea study, a negative sla was selected and surveyed in April 1999 (Mouriño et al., 2002). This elongated east-west Storm eddy (ellipticity 0.4), with centre near $32^{\circ} \mathrm{N}, 29^{\circ} \mathrm{W}$, called Leticia, L, was on travel curve 7 at the time of this survey. Back tracking the negative sla for Leticia in time gave an origin near $26^{\circ} \mathrm{W} \sim 300$ days earlier. Extrapolating forward gave a final position near $27.5^{\circ} \mathrm{W}$. Storm Leticia moved between travel curves $(6$ and 7) but no Lagrangian measurements or direct measurements are available to prove that the same water parcel has been followed for 400 days. The weakening and intensifying of eddy structure might suggest wavelike transfer of energy. It is evident that there are 14 or 15 negative sla travel curves in the 8-y period considered, $\sim 9$ after Storm 0 and 5 or 6 before giving a period of 183-209 days for repeating structure of similar sign, cyclonic or anticyclonic, near $32.5^{\circ} \mathrm{N}$, $32.5^{\circ} \mathrm{W}$. As with conditions at $26^{\circ} \mathrm{N}$, there is ocean climate. In the region to the west, the structures are intensified in 1995 and 1999. The groups of energy travel westward at about the same speed as the travel curve for Storm 0, 


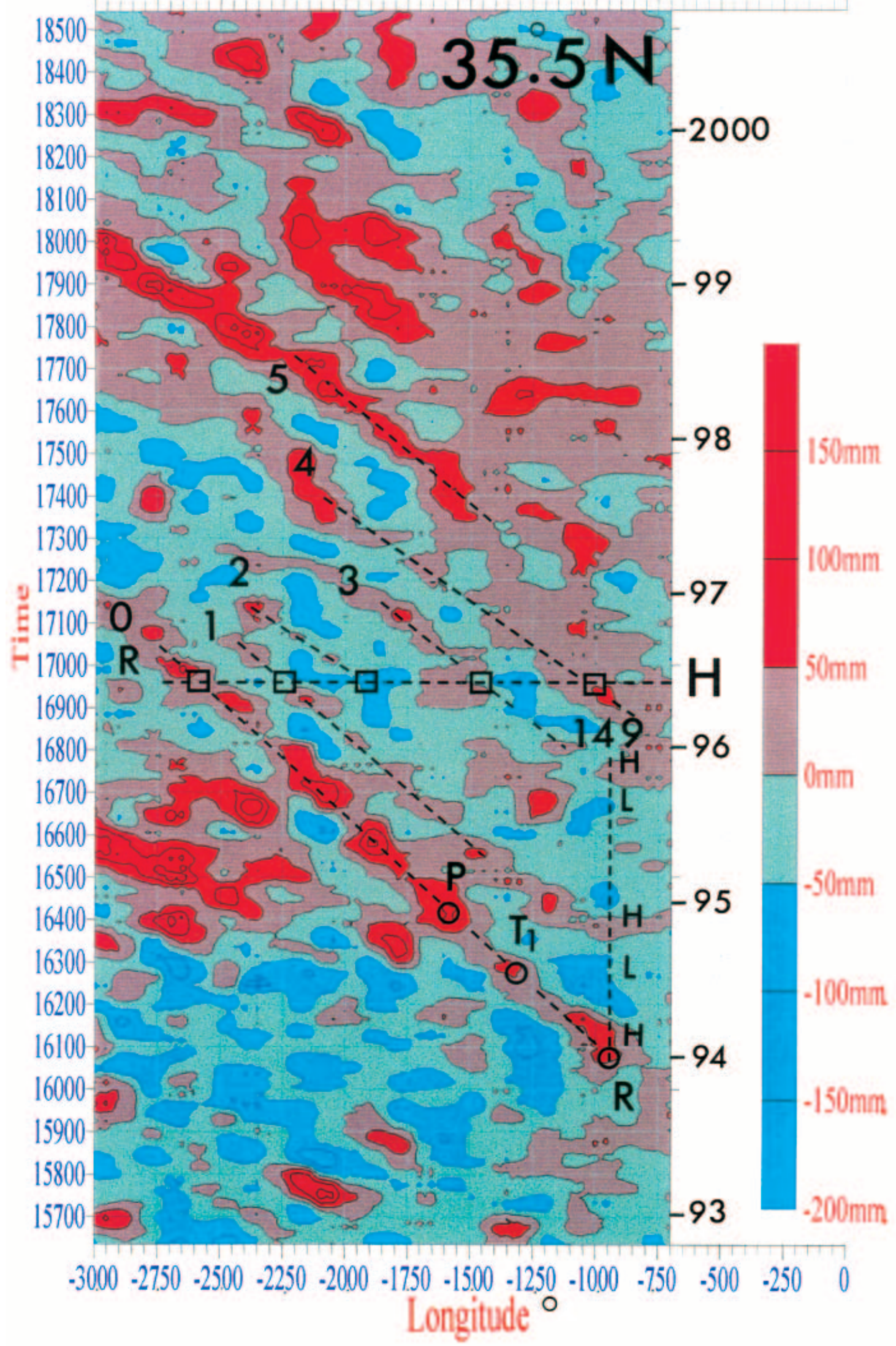

Figure 12. Summary of westward propagating disturbances at $35.5^{\circ} \mathrm{N}$ observed by altimeter, from $7^{\circ} \mathrm{W}$ to $30^{\circ} \mathrm{W}$ over an $8-\mathrm{y}$ period (Julian Days, JD). The altimeter signal is the sla $(\mathrm{mm})$ with the annual signal removed. R follows the positive sla line marked $\mathrm{R}$ or 0 with slope $1.8 \mathrm{~cm} \mathrm{~s}^{-1}$. Intercepts of $\mathrm{R}$ with $\mathrm{T} 1$ and $\mathrm{P}$ are marked and interaction between eddies or wave eddy superposition is seen by local increases in sla intensity along the travel line at these points. The track of HMS 'Hecla' is shown as a dashed line $(\mathrm{H})$ at JD16960. Positive sla travel lines $0,1,2,3,4$ intersect Hecla's track at $26^{\circ}, 22.5^{\circ}, 19^{\circ}, 14.5^{\circ}$ and $10^{\circ} \mathrm{W}$ (see Figure 10). Data line for Cape St Vincent Rig 149 is shown dashed with H, L annotations (see Figure 13). 


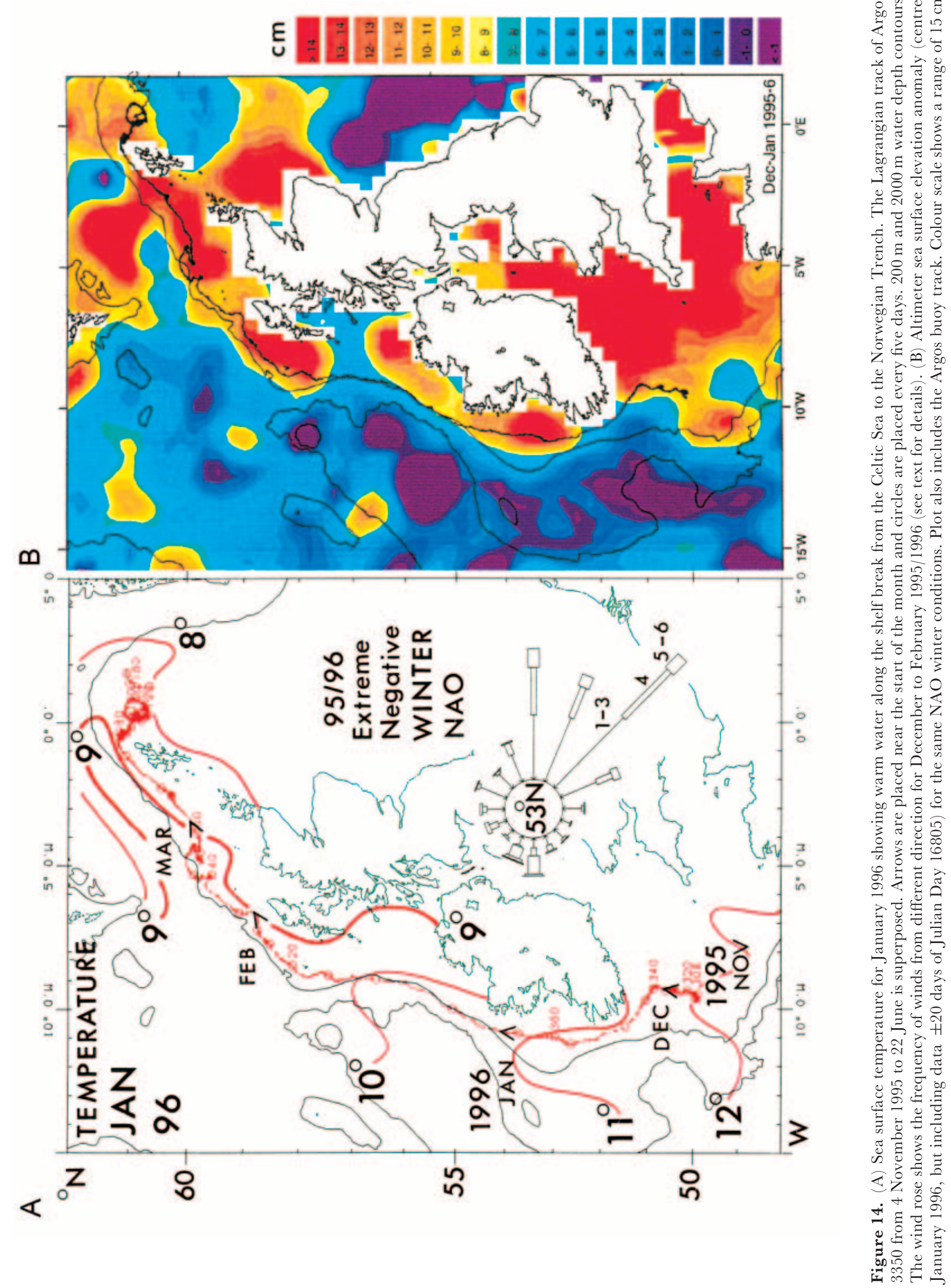




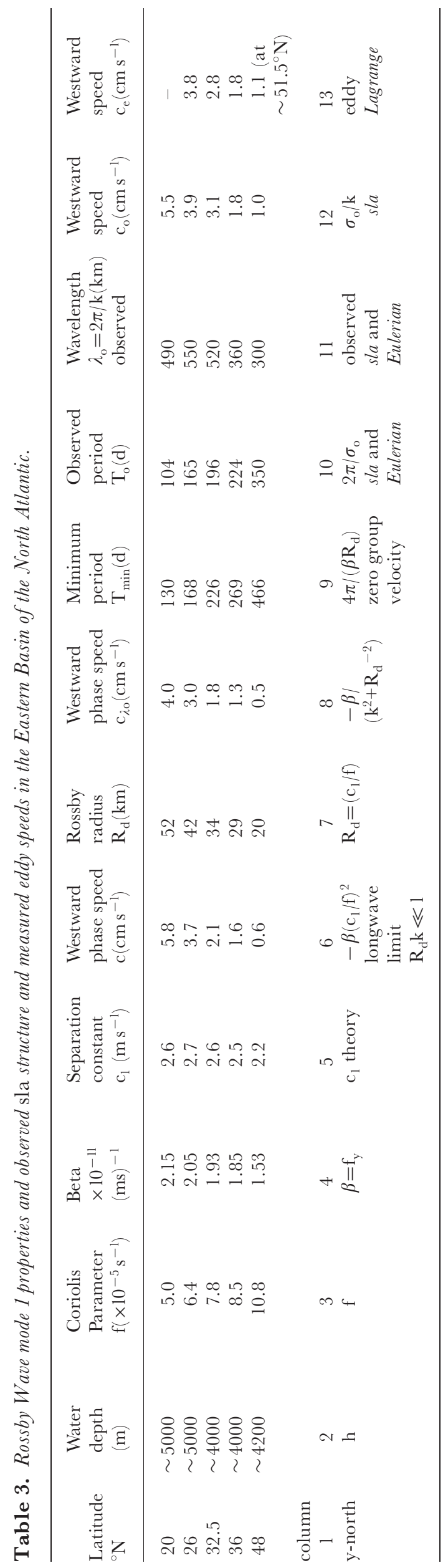




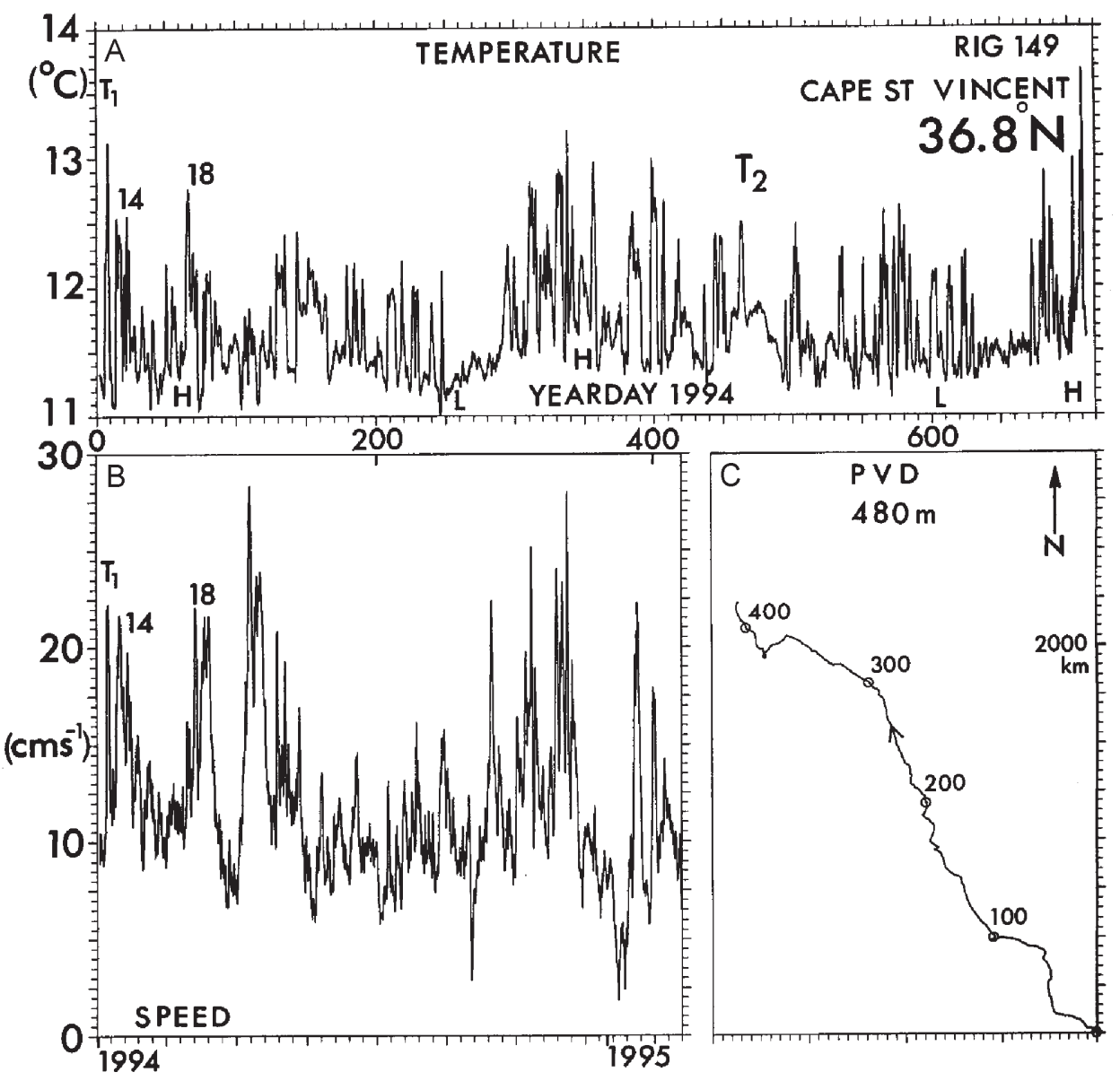

Figure 13. (A) Two year temperature record $\left({ }^{\circ} \mathrm{C}\right)$ at $480 \mathrm{~m}$ depth against yearday 1994 at Cape St Vincent Spur, Rig 149 , showing timing of Meddy 14 and 18 at the rig position. Highs and lows of longer period temperature changes are marked $H$ and $L$ (see Figure 12). T1 passed the rig position before Meddy 14 and T2 is an estimated time at the rig position (see text). (B) Speed record $\left(\mathrm{cm} \mathrm{s}^{-1}\right)$ also identifying Meddies 14 and 18. (C) PVD for Rig 149 with annotations every 100 days (YD1994); 2000 km scale shown. $24 \mathrm{~h}$ averaging has been applied to the calibrated data.

showing that phase speed and group velocity are about equal. The sla negative anomalies (e.g. Storm 0) are associated with more intense deepening (or negative central value) than the positive steepening in the centre of the anticyclonic sla structures, or an eddy field with more intense cyclones. There is also a broad band of slightly positive sla in the central region in $\sim 1999$ which relate to ocean circulation. The intensification of eddy structure seen in $1994 / 1995$ might result in the adjustment process as the Subtropical Gyre increases in strength, 1995 and 1999/ 2000 were years when the circulation increased to maximum values (see later).

The overall conclusion from this section is that eddies near $32.5^{\circ} \mathrm{N}$ have wavelike properties and travel westward at the same speed as other westward propagating structure. However, transfer of energy between eddies or eddy splitting and merging can result in a loss of eddy identity or integral property and so the Lagrangian eddy speed may not always be the same as the westward sla travel speed $\sim 3 \mathrm{~cm} \mathrm{~s}^{-1}$. At this latitude $\left(\sim 32.5^{\circ} \mathrm{N}\right)$ in the Eastern Basin, the mean stability increases from deep to shallower levels with a maximum Brunt-Vaisala Frequency, N, located in the permanent thermocline. At $\sim 500 \mathrm{~m}$ depth where the highest correlation between sla and temperature was found, $\mathrm{N}$ is typically $\mathrm{N}=2.5 \mathrm{cph}$. The sla surface signal reflects surface geostrophic currents resulting from internal ocean isotherm displacement in the permanent thermocline which have a maximum peak to trough amplitude of $300 \mathrm{~m}$ at $300 \mathrm{~m}$ depth. The southward transport for the Subtropical Gyre in 1996 at the latitude of the 'Hecla' section (Figure $4 \mathrm{~A}$ ) from $20^{\circ} \mathrm{W}$ to $50^{\circ} \mathrm{W}$ was $28 \mathrm{~Sv}$ with a 3000 dbar reference level.

\section{Azores Current $34-35^{\circ} \mathcal{N}$ (Meanders)}

The Azores Current (AC) lies at $\sim 34^{\circ} \mathrm{N}$ in the Eastern North Atlantic. Its position based on drogued buoy tracks and ALACE subsurface floats is shown in Figure 6. The AC separates Subtropical Water from Eastern North Atlantic Central Water. Even at a depth of $1000 \mathrm{~m}$, the salty core of Mediterranean Water lies to the north of the $\mathrm{AC}$. In the $\mathrm{AC}$ region at $34-35^{\circ} \mathrm{N}$, it is difficult to separate out meanders from eddies. An eastward meandering Lagrangian track in the AC may simply reflect an eastward path through alternate adjacent cyclonic and anticyclonic eddies. Argos buoys with drogues set at $200 \mathrm{~m}$ depth showed wavelike or meander features near $25^{\circ} \mathrm{W}$ as they moved rapidly $\left(\sim 20 \mathrm{~cm} \mathrm{~s}^{-1}\right)$ eastward (e.g. buoy 3909 , Pingree, 1997). Two meanders were separated by $\sim 400 \mathrm{~km}$ and if it is assumed that the meanders or eddies forcing 


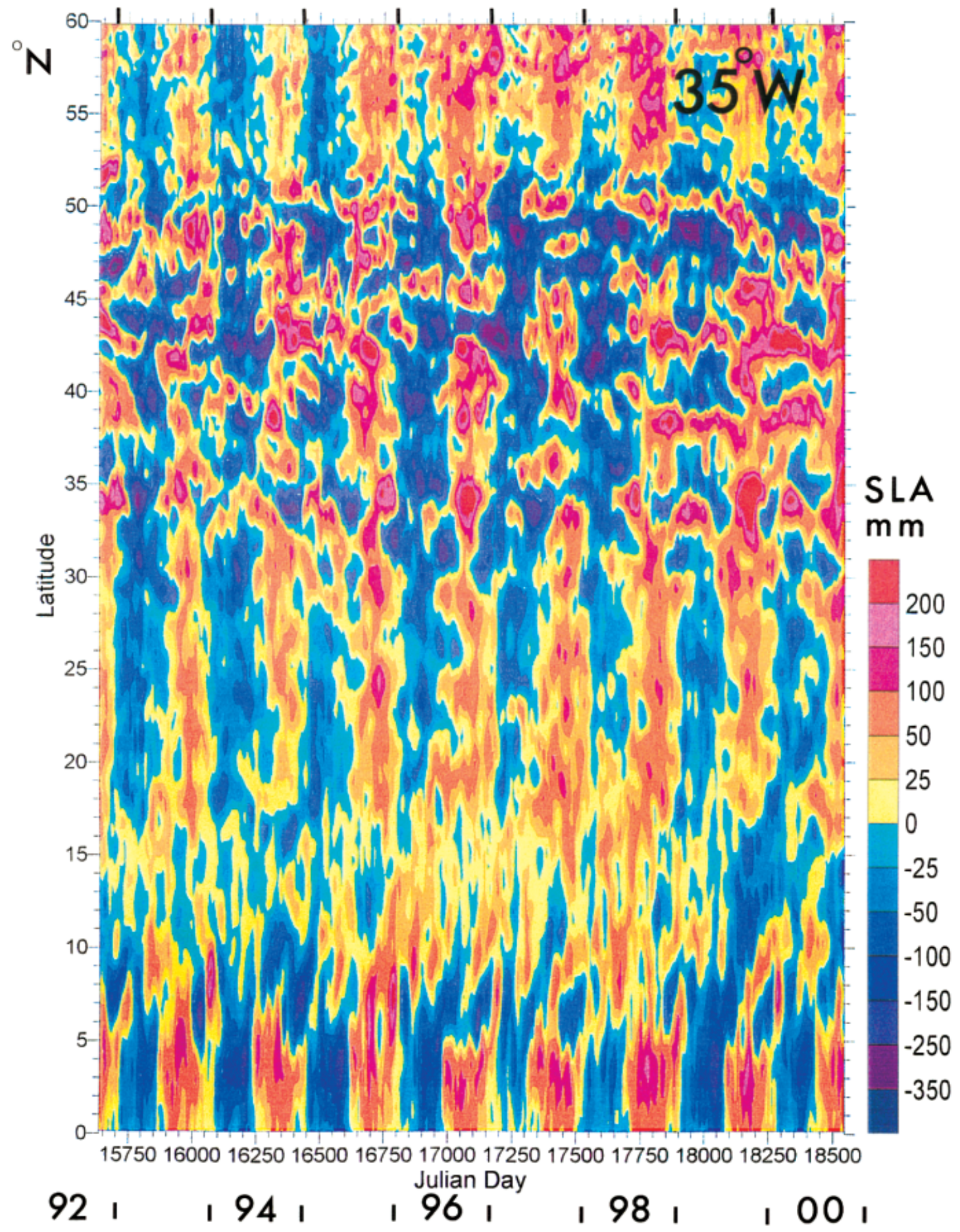

Figure 15. Sea level anomaly or sla (in mm) derived from altimeter data across the North Atlantic Ocean from $0^{\circ}$ to $60^{\circ} \mathrm{N}$ at $35^{\circ} \mathrm{W}$ against Julian Day covering an 8-y period (see text for details) showing scale of westward propagating structures against latitude and climate trends.

the meanders also move westward at $\sim 3 \mathrm{~cm} \mathrm{~s}^{-1}$ then a wavelength of $\sim 450 \mathrm{~km}$ is obtained for $34.5^{\circ} \mathrm{N}$. In the eastern extension, the AC can flow to the south or north. Deep drogued $(1000 \mathrm{~m})$ and surface ARGOS buoys showed south-west flow along the Eastern Boundary (figure 29 of Pingree (1997)) to the Canary Islands. Buoy 3916 (200 $\mathrm{m}$ drogue) reached $\sim 34.5^{\circ} \mathrm{N}, \quad 8^{\circ} \mathrm{W}$ (the Moroccan slope) from a position south of the Azores $\left(35^{\circ} \mathrm{N} 26^{\circ} \mathrm{W}\right)$ and then went north-west, taking a year and a half to arrive off Cape St Vincent. ALACE 25973 at $\sim 740$ dbar was even more remarkable. 25973 was released in Storm 0 near $33.5^{\circ} \mathrm{W}\left(32.5^{\circ} \mathrm{N}\right)$ in October 1995 and subsequently moved in the AC/Subtropical Front region (Pingree \& Sinha, 2001). The subsurface float then took the northward branch or anticlockwise recirculation of the $\mathrm{AC}$ and arrived $\left(38.7^{\circ} \mathrm{N}, 11.1^{\circ} \mathrm{W}\right)$ west of Lisbon (at 580 dbar, $11.1^{\circ} \mathrm{C}$ ) in the Tagus Abyssal Plain (Figure 6) in January 2002, a journey time of 2278 days (6.2 y). By May 2002, 25973 had moved west and was near $38.9^{\circ} \mathrm{N}, 12.3^{\circ} \mathrm{W}$, just south of the Tore Seamount ring. Hence in the east, a 


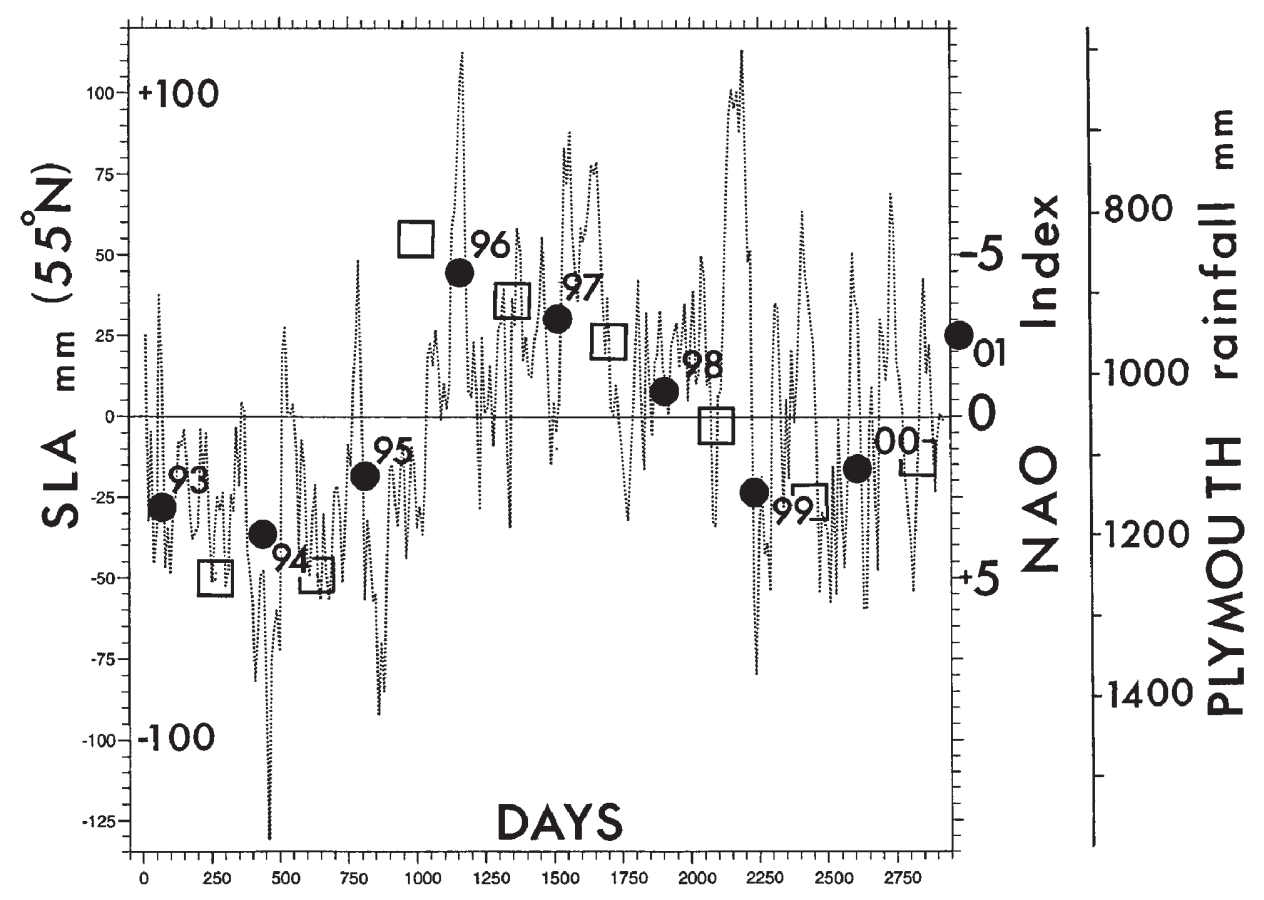

Figure 16. Sea level anomaly or sla (in mm) for a central region of the subpolar North Atlantic at $55.5^{\circ} \mathrm{N} 35^{\circ} \mathrm{W}$ with the annual signal removed (dotted) and values of winter NAO (November, December and January) index (bold dots) against days from October 1992 to October 2000. The numbers 93 (1993) to 01 (2001) are placed near the start of the year (1 January). Open squares are Plymouth annual rainfall in $\mathrm{mm}$.

branch of the AC enters the Seine Abyssal Plain, sometimes even passing in a clockwise sense around Unicorn Seamount before continuing east. The eastward extension of the AC makes the eastern Seine Abyssal Plain, near $(\sim 300 \mathrm{~km})$ the Mediterranean Outflow, fresher and cooler at a depth of $\sim 1000 \mathrm{~m}$ than the western Horseshoe Abyssal Plain (see later CD66 and Hecla cross sections) which is $\sim 800 \mathrm{~km}$ from the Outflow. The southward transport near $34^{\circ} \mathrm{N}$ for the CD66 CTD data from $30^{\circ} \mathrm{W}$ to $9^{\circ} \mathrm{W}$ was $22 \mathrm{~Sv}$ with a 2000 dbar reference level.

\section{Waves and eddies at $35-37^{\circ} \mathcal{N}($ Meddy)}

A MEDDY is a coherent clockwise-rotating (anticyclonic) rotating lens of warm salty Mediterranean Outflow Water, or an EDDY in the North Atlantic with a core of Mediterranean Water. The most comprehensive Meddy studies to date are those of Richardson et al. (2000) and Bower et al. (1997). A Meddy has an aspect ratio of $\sim 1-2 \%$. Here we use data from 2-y long current meter records from Rig 152 and float data to examine the relation between Meddies and westward propagating sla disturbances at $36^{\circ} \mathrm{N}$. It is necessary to present a significant amount of unpublished data to make the next sections coherent and plausible.

\section{Rig 152, two years in the southern Tagus, $36.5^{\circ}$ N: T0, T1, T2}

In March 1992, a Meddy with a dynamic core at the level $(\sim 700 \mathrm{~m})$ of the Secondary Mediterranean salinity maximum called Smeddy Tagus (T0) was surveyed in the Tagus Abyssal Plain (PML, 1992). A drogue was set at a depth of $800 \mathrm{~m}$ and tethered to a surface Argos buoy. T0 was tracked from the Tagus Abyssal Plain to the Horseshoe Abyssal Plain over a 3-week period (Figure 6). At the end of December 1993, Rig 152 was deployed (PML, 1994) in the gap between Hirondelle Seamount and Gorringe Ridge (subseqently referred to by just gap) in a water depth of $3770 \mathrm{~m}$ to count the Meddies passing to the Horseshoe Abyssal Plain through this gap. The easiest way to see whether a Meddy has passed a deep ocean mooring is to look at the knock-down of the rig. The drag of currents of order $\sim 1 \mathrm{kn}$ across the upper kilometre of a rig will cause even the stiffest moorings in deep water to cant over. Three Meddies were found in the 2-y record; two with a marked signal. These Meddies were evident in the progressive vector diagram for the current meter record at a nominal depth of 820 dbar (current meter 3115, Table 2) and are labelled 11, T1 and T2 in Figure 7. Meddy 11 is called 11 as this Meddy was identified in Richardson et al. (2000). The timing of T1 at the rig position also shows that the end of the Richardson et al. (2000) Meddy 15 and the start of Meddy 19 were the same Meddy. This also tells us that Tl passed Cape St Vincent near 1 January 1994. Meddy 11 did not pass through the gap and the nearest approach of its centre to the mooring was $\sim 70 \mathrm{~km}$. Its signal in the current meter record was much less marked than that of $\mathrm{T} 1$ and $\mathrm{T} 2$ whose centres passed within $\sim 15 \mathrm{~km}$ of the rig position as they moved southward onto the Horseshoe Abyssal Plain. Tl showed instantaneous maximum currents of $44 \mathrm{~cm} \mathrm{~s}^{-1}$ and $\sim 100 \mathrm{~m}$ knock-down of the mooring at the level of current meter 3115. Maximum currents at $545 \mathrm{dbar}$ (current meter 2068) were $35 \mathrm{~cm} \mathrm{~s}^{-1}$. Maximum calibrated temperatures of $12.8^{\circ} \mathrm{C}$ (at $837 \mathrm{dbar}$ ) were recorded for the core of $\mathrm{Tl}$ as its centre passed nearest the rig (but to the west) on YD153 (1994). The next conspicuous Meddy signal occurred $\sim 470$ days later as T2 passed south and its centre was closest to the rig position on yearday 624 


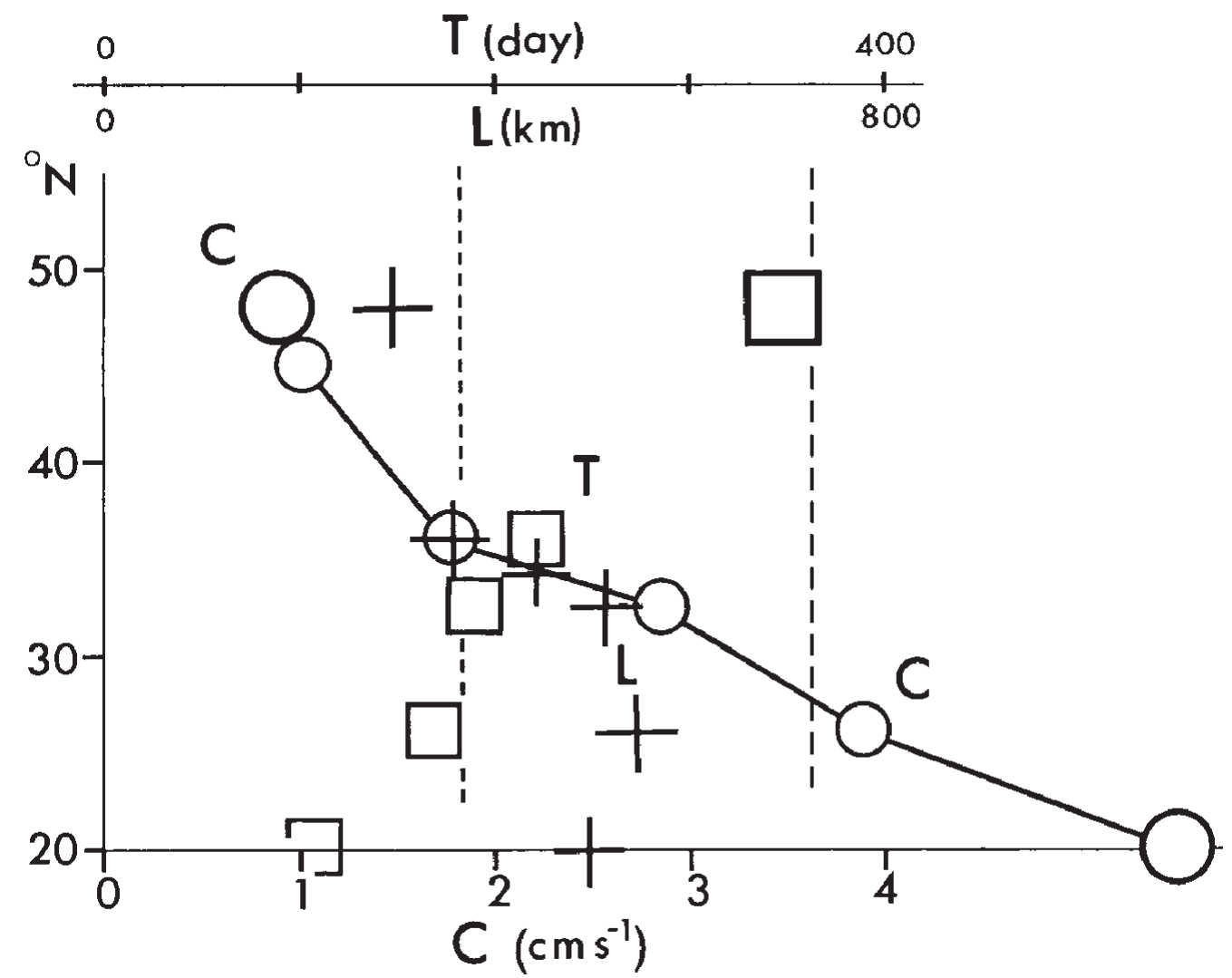

Figure 17. Summary characteristic for eddies and waves showing wavelength, L (or L/2 for eddy scale, crosses), period, $\mathrm{T}$ (squares), westward travel speed, c (circles joined as a continuous line), from $20^{\circ}-50^{\circ} \mathrm{N}$. Dashed lines show annual and semi-annual periods; size of symbols indicates a measure of variability.

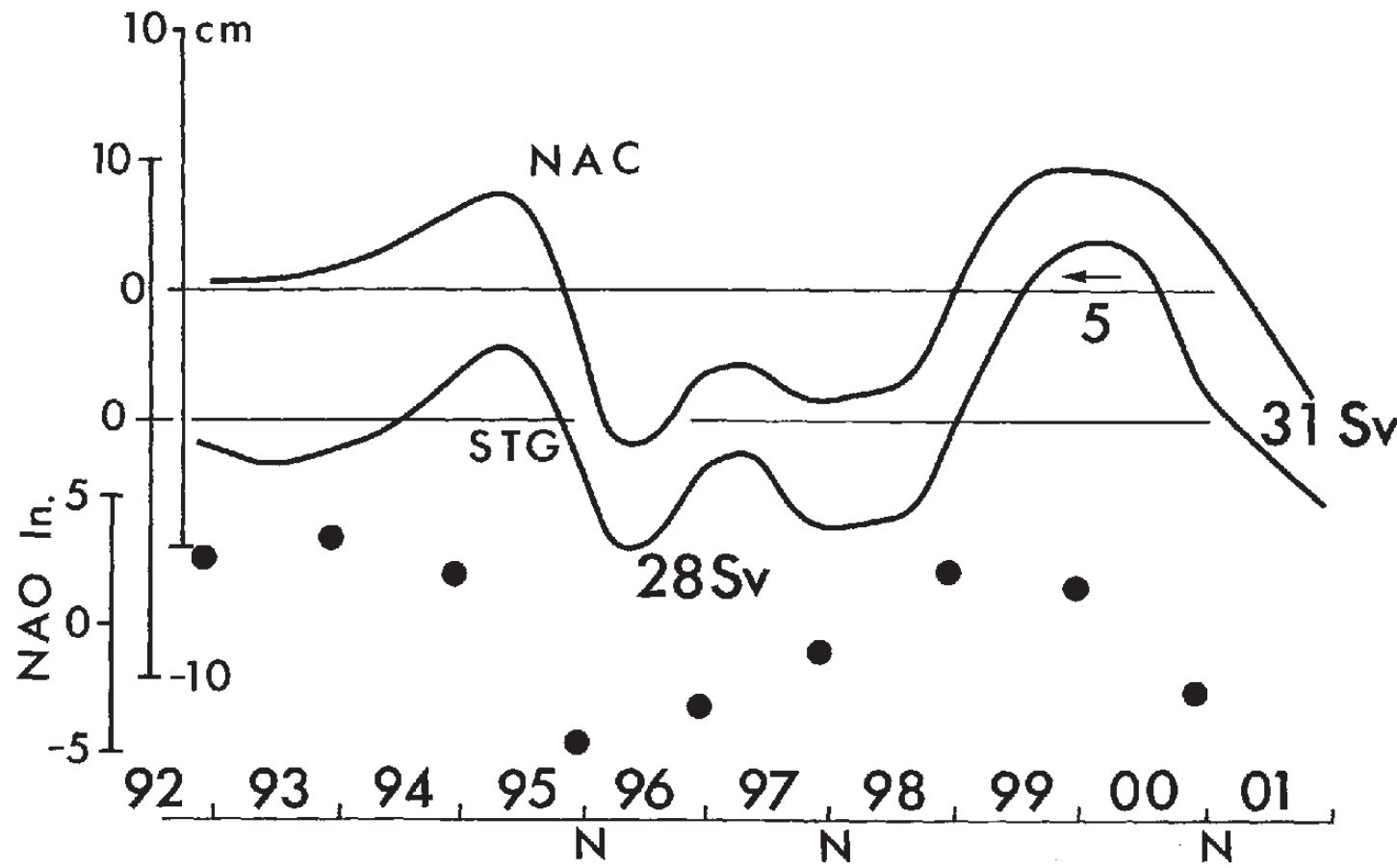

Figure 18. Summary diagram of North Atlantic Gurrent Strength Index (NAG), Subtropical Gyre Strength Index (STG) with offset scale and NAO Winter Index from 1992 to 2002. The scale units for NAC and STG are sea level differences between BA and BC marked in Figure $1 \mathrm{in} \mathrm{cm.} \mathrm{In} \mathrm{1996,} \mathrm{a} \mathrm{value} \mathrm{of} 28 \mathrm{~Sv}$ was calculated for the STG. The 0 line represents the mean transport $\sim 31 \mathrm{~Sv}$ for the STG over a 9-y period. The 5 with westward arrow shows that the annual mean current in the North Equatorial Current or Subtropical Gyre return flow from mid year 1999 to mid year 2000 at $16.5^{\circ} \mathrm{N}$ was $5.3 \mathrm{~cm} \mathrm{~s}^{-1}$ westward (Table 1). N below the year scale shows that January 1996, 1998 and 2001 were Navidad years (see Figure 14) with enhanced dynamic height gradient between Portugal and Ireland and poleward flow of warm water along the Eastern Boundary. 
(1994). This Meddy oscillated approximately east-west before passing through the rig position in a south-west direction (see Figure 7). Maximum recorded speeds were $40 \mathrm{~cm} \mathrm{~s}^{-1}$ as T2 passed through the gap. The core temperature was $12.6^{\circ} \mathrm{C}$ (at $820 \mathrm{dbar}$ ) and the minimum speed recorded in the warm water core was $8 \mathrm{~cm} \mathrm{~s}^{-1}$. The weak currents in the Meddy centre meant that there was no knock-down when this Meddy centre was closest to the rig position. The centre of Meddy $\mathrm{T} 2$ passed within a few kilometers $(\sim 3 \mathrm{~km}$, based on the azimuthal speed against radius or rotation period, see for example, Hedstrom \& Armi, 1988; Pingree \& Le Cann, 1993) to the east of the position of Rig 152 so T2's eastern flank was adjacent to Gorringe Ridge, with the top of Gettysburg Seamount (whose summit rises to $25 \mathrm{~m}$ ) only $60 \mathrm{~km}$ east of the Meddy centre.

A mean rate of Meddies through the seamount gap of every $\sim 400$ days, $\sim 2$ in two years or one a year is too low a value to account for all the Meddies moving south onto the Horseshoe Abyssal Plain so Meddies initially moving north past Cape St Vincent are also channelled south to the west of Hirondelle Seamount. It is clear that current meter moorings must be deployed for long periods (as at $32.5^{\circ} \mathrm{N}$ ) to give meaningful residual flow statistics, but a few strategically placed rigs could easily count the Meddies moving south at a fixed latitude.

Just two Meddy signals (T1, T2) dominated the residual current for the 2-y long record. If we include the Meddies, then the residual flow over a $2-y$ period (711 days, see Table 2) at $820 \mathrm{dbar}$ is $3.6 \mathrm{~cm} \mathrm{~s}^{-1}$ to the south-south-west or $203^{\circ} \mathrm{T}$. At $370 \mathrm{dbar}$, the mean flow is $4.9 \mathrm{~cm} \mathrm{~s}^{-1}$ at $222^{\circ} \mathrm{T}$, over a period of 487 days. The Meddies, T1 and $\mathrm{T} 2$ took $\sim 80$ days to pass through the rig position and so for $\mathrm{a} \sim 100 \mathrm{~km}$ diameter Meddy the southward movement at $820 \mathrm{dbar}$ is $\sim 1.4 \mathrm{~cm} \mathrm{~s}^{-1}$ (see also Table $1,1.1 \mathrm{~cm} \mathrm{~s}^{-1}$ ) which is very comparable to the mean value $\left(\sim 1.4 \mathrm{~cm} \mathrm{~s}^{-1}\right.$ south $)$ derived by Richardson et al. (2000), suggesting in this case little retarding or restricting influence of topography. If the orbital motion of the Meddies is removed from the PVD at $\sim 800 \mathrm{~m}$ then the background flow becomes westward at $\sim 2.8 \mathrm{~cm} \mathrm{~s}^{-1}$ suggesting that the Meddies T1 and T2 were not swept south through the seamount gap. This contrasts with the case of Smeddy Tagus (T0) which was advected south through the gap at a speed of $\sim 5 \mathrm{~cm} \mathrm{~s}^{-1}$ (Pingree \& Le Cann, 1993).

\section{WOA94 hydrographic sections}

One of the best tracers for Mediterranean Water is salinity (Lacombe \& Tchernia, 1960; Arhan, 1987) and WOA94 sections show the Mediterranean core clearly. At $30^{\circ} \mathrm{W}$, well to the west of the Madeira-Tore Rise, the salinity maximum near 1000 dbars is centred at $\sim 34^{\circ} \mathrm{N}$. At $20^{\circ} \mathrm{W}$, the salinity core is centred rather further north $\sim 36-37^{\circ} \mathrm{N}$ (Figure 8) and, at $12^{\circ} \mathrm{W}$, the broad core centre is near $\sim 38-39^{\circ} \mathrm{N}$ or located in the northern Tagus Abyssal Plain (Shapiro \& Meschanov, 1996). In the Tagus Abyssal Plain, the Mediterranean core receives a source of salt from Meddies leaving the Iberian slope region from Cape St Vincent to the Tejo Plateau, 3 degrees of latitude north of the Strait of Gibraltar. Meddies have recently been discovered as far north as the Bay of Biscay (Paillet et al., 1999). Regions influenced by Mediterranean Water can also be characterized using temperature as a tracer. At large distances from the source or in regions not markedly or recently affected by the Outflow water, the salty Mediterranean presence is accompanied by a thickening of the $10-11^{\circ} \mathrm{C}$ isotherm band which is $\sim 300 \mathrm{~m}$ thick at $20^{\circ} \mathrm{W}$ in the salty core illustrated in Figure 8 (the $11-12^{\circ} \mathrm{C}$ isotherm band is $\sim 200 \mathrm{~m}$ thick). Closer to the Outflow, east of the Madeira-Tore Rise but north of $\sim 35^{\circ} \mathrm{N}$ or in the Horseshoe Abyssal Plain, an increase in thickness of the $11-12^{\circ} \mathrm{C}$ isotherm band is more apparent $\left(\sim 500 \mathrm{~m}\right.$ thick at $38-39^{\circ} \mathrm{N}, 12^{\circ} \mathrm{W}$ near Tore Seamount, just north of the Tagus Abyssal Plain, WOA94 data). Once the temperature characteristics of Mediterranean Water are identified, CTD and XBT temperature profiles can be combined to produce long sections with a resolution (e.g. Figures 2 or $4 \mathrm{~A}$ ) that is not often possible to achieve with salinity sections.

\section{CD66 CTD/XBT section 34-37 $\mathcal{N}$, March 1992}

A south to north XBT/CTD section (PML, 1992) through the Horseshoe Abyssal Plain, but keeping parallel with and $\sim 200 \mathrm{~km}$ from the upper continental slope north of the Strait of Gibraltar (see Figure 6) shows that the Horseshoe Abyssal Plain is markedly influenced by the Outflow with a variable but thickening band of temperature in $11-12^{\circ} \mathrm{C}$ range, i.e. north of $\sim 35^{\circ} \mathrm{N}$ (Figure 9 ). In the southern Tagus Abyssal Plain, the thickness of this band increases to $800 \mathrm{~m}$ with measured salinities of $36.4 \mathrm{psu}$ in the Intermediate Mediterranean Salinity Maximum (Pingree \& Le Cann, 1993). Unlike the WOA94 data, this $500 \mathrm{~km}$ section is synoptic with $\sim 20$ stations completed in two days. The main point here is that there is plenty of excess salty water in the Tagus Abyssal Plain that may be relieved by intermittent transfer of Meddies to the Horseshoe Abyssal Plain. One Meddy (Smeddy Tagus, T0) moved south through the gap from the Tagus to the Horseshoe Abyssal in April 1992 shortly after this surveyed section in March 1992. Although the eastern part of the section $\left(\sim 34-35^{\circ} \mathrm{N} 9^{\circ} \mathrm{W}\right)$ through the Seine Abyssal Plain is near the Mediterranean Outflow, the thickness and depth of temperatures in the $10-12^{\circ} \mathrm{C}$ range are more comparable with those west of the Horseshoe Abyssal Plain at $15-20^{\circ} \mathrm{W}$. The Seine Abyssal Plain with minimal isotherm thickening is kept relatively fresh by the AC (see Figure 6).

\section{Hecla XBT section $34-36^{\circ} \mathcal{N}$, June 1996}

The $1700 \mathrm{~km}$ (using 61 T5 profiles) Hecla XBT section (Figure 10) ran through the Horseshoe Abyssal Plain and this sub-section of a complete North Atlantic crossing was completed in three days. A thickening of the $10-11^{\circ} \mathrm{C}$ isotherm band is apparent near $26^{\circ} \mathrm{W}$ and this temperature band increases to a thickness of $\sim 250 \mathrm{~m}$ at $20^{\circ} \mathrm{W}$. Towards the eastern end of the section in the Horseshoe Abyssal Plain or east of $\sim 15^{\circ} \mathrm{W}$, the isotherm thickening spreads into the $11-12^{\circ} \mathrm{C}$ isotherm band which thickens to $800 \mathrm{~m}$ locally. In common with other long sections (i.e. at $26^{\circ} \mathrm{N}, 32.5^{\circ} \mathrm{N}, 48^{\circ} \mathrm{N}$ ), there is the suggestion of repeating structure, in this case, with more deeply penetrating structure at $25.5^{\circ} \mathrm{W}, 22.5^{\circ} \mathrm{W}, 18.5^{\circ} \mathrm{W}, 14.5^{\circ} \mathrm{W}$ and $10^{\circ} \mathrm{W}$. We cannot say whether any of these disturbances are due to Meddies as we have no Lagrangian observations at this latitude and time. Even if one of the structures is a Meddy, we know that on average it will be travelling southward 
through the section pattern. We assume, as before, that there are wavelike disturbances propagating westward and that eddies are caught up with or in some cases have the same westward speed as the westward propagating waves. We note however, that there is little undulation of this structure in the upper layers, expected for a mode 1 oscillation, but there are domed structures at $28^{\circ} \mathrm{W}, 24^{\circ} \mathrm{W}$, $21.5-19.5^{\circ} \mathrm{W}$ and $13.5^{\circ} \mathrm{W}$. The wavelength for the repeating more deeply penetrating anticyclonic structure is $\sim 340 \mathrm{~km}$.

\section{Pinball, one year track}

Meddy Pinball, P, was surveyed 4-9 January 1994 (PML, 1994; Pingree, 1995) and 2 drogued Argos buoys (5030, 5031), 2 ALACE (21076, 21077) and 2 RAFOS floats $(136,137)$ were launched into the Meddy core (Table 1). The Argos buoy drogued at $750 \mathrm{~m}$, with $\sim 7$ realtime fixes a day, gave a solid body rotation period of 2.4 days over a period of $\sim 7$ weeks. Pinball moved west towards Ashton Seamount and then back towards Lisbon Canyon (Figure 11). Pinball was tracked to Ashton Seamount about half a year after the initial survey and, based on RAFOS float 137 (Richardson \& Wooding, 1999), its rotation period had only fallen to 2.7 days, a slowing of $\sim 25 \%$ a year. After $\sim 200$ days ( YD200 1994), Pinball collided with or absorbed Meddy 18 (Richardson et al., 2000) and the coalesced structure, now called Pinball18, P18, continued on a south-west track towards Lion Seamount channelled along the eastern side of the seamount chain (MadeiraTore Rise) that forms the western boundary of the Tagus and Horseshoe Abyssal Plains (Figure 6). ALACE 21077 left Pinball after $\sim 200$ days and Richardson et al. (2000) have shown that exiting of Lagrangian followers can occur when Meddies interact. In December 1994, P18 reached a position just to the north-east of Lion Seamount at the western end of Horseshoe Abyssal Plain to give a track of 330 days. A final Lagrangian position for YD350 based on RAFOS 137 shows P18 over Lion Seamount.

\section{Remote sensing signature of Meddies}

Meddies can have a remote sensing signature even though their core is at a depth of $1 \mathrm{~km}$. For example, a sequence of infra-red (IR) images for the position of Meddy Pinball in April 1994 showed anticyclonic rotation of the sea surface caused by the core below (Pingree, 1995). Infra-red images were also examined for the period T0 was in the Southern Tagus Abyssal Plain (March, 1992) and as Tl passed Rig 152 (June 1994). The NOAA 11 image for 11.06 .94 (overhead time 1648 GMT; yearday 162) nine days after the nearest approach of the Meddy centre to Rig 152 (yearday 153) shows an anticyclonic temperature feature of $\sim 85 \mathrm{~km}$ diameter with apparent centre $\sim 20 \mathrm{~km}$ south of the mooring position consistent with the structure seen in the PVD (Figure 7). Meddies will have an altimeter signal (see Stammer et al., 1991) if the azimuthal currents with maximum values located at the core level extend to the sea surface. Meddy Pinball could be followed as a positive anomaly in sla maps for extended periods. The upper current meter record on Rig 152 ( 370 dbar) showed significant near surface currents $\left(\sim 30 \mathrm{~cm} \mathrm{~s}^{-1}\right)$ as Tl passed the rig and this Meddy had a clear altimeter positive sla for $\sim 2$ months, from $\sim 14.06 .94$ (YD165) to 13.08.94 (YD225), see next section Sla track for $R$. If a Meddy does not have a
Taylor Column with currents to the surface then it will not have an altimeter expresssion.

\section{Sla track for $R$}

A conspicuous positive sla was observed early January 1994 at a position near $9.3^{\circ} \mathrm{W}, 35.0^{\circ} \mathrm{N}$ at the south-east entrance to the Horseshoe Abyssal Plain, at the same time as Pinball left the continental slope west of Lisbon (7 January). This sla was called anomaly R, R standing for Meddy (Richardson et al., 2000) or wave (Rossby) or Reference sla but it could have been T for Meddies (T0, T1, T2) and 'Taylor Wave'. $\mathrm{R}$ was followed in the manner of Pingree et al. (1999a) which insists on continuity of structure so that some integral part of a feature is being followed. This method of tracking (as opposed to travel curves at the fixed latitudes presented here) allows the anomaly to change latitude and can flag merging with other structures or splitting of structure. $\mathrm{R}$ moved relatively slowly west for the first 100 days and then moved quickly to $12.5^{\circ} \mathrm{W}$ where $\mathrm{R}$ passing slowly along the northern flank of Ampère Seamount collected Tl passing through the gap between the Tagus Abyssal Plain and the Horseshoe Abyssal Plain (Figure 11). The apparently merging structure, now called RTl, remained in the vicinity of Ampère Seamount for $\sim 100$ days before moving fairly rapidly westward again to Lion Seamount. Here it remained for $\sim 100$ days 'waiting' for Pinball which arrived north of Lion Seamount $\sim 322$ days after it left the continental slope near Lisbon. The apparently combined structures R, T1, P, 18 now called RTP were evident as a more marked positive sla for a further $\sim 50$ days at $\sim 16^{\circ} \mathrm{W}, 35.4^{\circ} \mathrm{N}$, adding a further $50-100$ days to the case history of Pinball. The total time taken for $\mathrm{R}$ (and its mixed structure or dilution by Meddy collisions) to travel 7 degrees of longitude was $\sim 400$ days giving a westward speed of $1.6 \mathrm{~km} \mathrm{~d}^{-1}\left(1.8 \mathrm{~cm} \mathrm{~s}^{-1}\right)$, close to the mean westward Meddy speed $\left(1.4 \mathrm{~cm} \mathrm{~s}^{-1}\right)$ derived by Richardson et al. (2000) for the general region, which may include some Meddies that are retarded by topography. Overall, there is both topographic control and interaction or merging of Meddies in the Horseshoe and Tagus Abyssal Plains resulting in a mean westward speed of $1.8 \mathrm{~cm} \mathrm{~s}^{-1}$ near $36^{\circ} \mathrm{N}$. This value is effectively based on four Meddies. Meddy 18 started westward later $(\sim$ yearday 70, Bower et al., 1997) so the mean westward speed for Meddies near $36^{\circ} \mathrm{N}$ east of the Madeira-Tore Rise could be increased slightly, to $\sim 1.9 \mathrm{~cm} \mathrm{~s}^{-1}$.

\section{Wave and eddy travel curves at $36^{\circ} \mathcal{N}$}

In the preceding sections, a wavelength of $\sim 340 \mathrm{~km}$ and a westward speed of $1.8 \mathrm{~cm} \mathrm{~s}^{-1}$ was determined for structure near $36^{\circ} \mathrm{N}$. Here, we summarize all the observations near $36^{\circ} \mathrm{N}$ on the $8-\mathrm{y}$ plot of sla (Figure 12). $\mathrm{R}$ is first evident near the start of a conspicuous travel line with a mean speed of $1.8 \mathrm{~cm} \mathrm{~s}^{-1}$. This is the reference travel curve or line 0 . The addition of $\mathrm{T} 1$ on line 0 is indicated $\sim 180$ days later and P18 follows after a further 160 days. The reference curve can be followed for 1000 days so it is hard to avoid the conclusion that in addition to Meddies there is a wavelike motion that interacts or temporarily superposes with the Meddy currents to result in an enhanced or a reinforced surface positive sla signal which reveals more clearly both the wavelike motion and the 
Meddy positions. The Hecla XBT track is drawn on the sla plot (Figure 12) and it intersects positive sla travel curves 0, 1, 2, 3 and 4 at positions already identified in Hecla XBT section 34-36 $\mathcal{N}$, fune 1995 (see Figure 10). The negative sla structure is also seen to be domed upwards in the upper layer, near $21^{\circ} \mathrm{W}$ and $13^{\circ} \mathrm{W}$, for example. Fourier analysis of the sla structure at $35.5^{\circ} \mathrm{N}$ showed that the dominant period was near semi-annual with significant longer redshifted components near the semi-annual frequency. Either by eye or analysis a mean separation of $\sim 215$ days and a wavelength of $360 \mathrm{~km}$ is estimated for the travel curves of Figure 12. There are also longterm changes, for example, between 1996 and 1998 near $30^{\circ} \mathrm{W}$, the mean sla is negative and we shall see later that this corresponds to a weakening of the Subtropical Gyre.

\section{Rig 149, two years on Cape St Vincent Spur, $36.8^{\circ} \mathcal{N}$}

Structure at long (annual, semi-annual) periods is seen in the $\sim 2$-y (713 days, Table 2 ) current meter temperature record obtained at $480 \mathrm{~m}$ depth on Rig 149 deployed on the continental slope off Cape St Vincent in a water depth of $1506 \mathrm{~m}$ (Figure 13). This rig was positioned to measure the continental slope current or Mediterranean Water Outflow at $\sim 500 \mathrm{~m}$. The rig was placed on the spur (where the along-slope direction was north-south) and the mean current was determined as $8.0 \mathrm{~cm} \mathrm{~s}^{-1}$ in a direction of $320^{\circ} \mathrm{T}$ or off-slope, showing that some flow does not follow the local slope contours round the spur and into Cape St Vincent Canyon, which fills with warm salty Mediterranean Water. Maximum speeds reached $\sim 35 \mathrm{~cm} \mathrm{~s}^{-1}$, associated with Meddies or pulses of Mediterranean Outflow Water, but instantaneous speeds were far less than those measured $\left(\sim 1.3 \mathrm{~m} \mathrm{~s}^{-1}\right)$ by Price et al. (1993) at similar depths close to the source of the Outflow in the Gulf of Cadiz. Flow separation in a spur situation was also measured at Goban Spur during OMEX (Pingree et al., 1999b) and further slope current measurements were made by White \& Bowyer (1997). In the Meddy context, the gap between Gorringe Ridge and Cape St Vincent is known as the gateway for Meddies passing north of Gorringe Ridge (Zenk \& Armi, 1990). The Mediterranean Undercurrent continues along the continental slope and at Rig 147 on the $2000 \mathrm{~m}$ depth contour on the continental slope west of Lisbon the mean current over a period of two years at $712 \mathrm{~m}$ was $8.0 \mathrm{~cm} \mathrm{~s}^{-1}$ in a direction of $316^{\circ} \mathrm{T}$ (see also Arhan et al., 1991). The flow in the deeper Mediterranean Core at $1218 \mathrm{~m}$ depth was weaker with a $2-\mathrm{y}$ mean of $2.0 \mathrm{~cm} \mathrm{~s}^{-1}$ in a direction of $316^{\circ} \mathrm{T}$ (Rig 146). On a relatively short time scale, temperature disturbances or the signatures of Meddies moving north along the continental slope can be seen in the current meter temperature records (e.g. at Rig 149, Figure 13, with Meddy 14 in January (yearday 26) and Meddy 18 in March 1994 (yearday 70), see Bower et al., 1997 and Richardson et al., 2000). However, what is also important here is that there are longer period changes in temperature structure reflecting ocean climate and structure. The data line for Rig 149 is also drawn on the sla plot of Figure 12. Although not quantitative as derived at $32.5^{\circ} \mathrm{N}$ (see eqn 1), it is evident that the high $(\mathrm{H})$ and low $(\mathrm{L})$ temperature structures seen at Rig 149 (at $36.8^{\circ} \mathrm{N}, 1994-1996$ ) at $\sim 500 \mathrm{~m}$ depth correlate positively with sla changes in the same manner that was found at Rig 155 for a later 2-y period (1995-1998).
Waves and eddies at $44-52^{\circ} \mathrm{N}$

Deep $(>1000 \mathrm{~m})$ Eulerian currents are weak $\left(\sim 1 \mathrm{~cm} \mathrm{~s}^{-1}\right)$ at $48^{\circ} \mathrm{N}$ (Arhan et al., 1989). Propagating disturbances at $48^{\circ} \mathrm{N}$ were estimated (Nechvolodov, 1993) to have a westward speed of order $1 \mathrm{~cm} \mathrm{~s}^{-1}$ and a separation of $\sim 300 \mathrm{~km}$ based on a repeated XBT section across the North Atlantic Ocean from $8^{\circ} \mathrm{W}$ to $47^{\circ} \mathrm{W}$ which showed wavelike structure with peak to trough amplitudes of typically $150 \mathrm{~m}$ in the upper $\mathrm{km}$ of the water column. Similar westward speed characteristics of structure were observed in the sla travel curves (not shown). Further north near $51.5^{\circ} \mathrm{N}$, a Lagrangian study of a cyclonic and an anticyclonic eddy gave a mean westward speed of $1.1 \mathrm{~cm} \mathrm{~s}^{-1}$ for the average westward translation (Pingree \& Le Cann, 1991), though these eddies appeared partially trapped to the south-west flank of East Thulean Rise. Similar westward trends $\left(1.8 \mathrm{~cm} \mathrm{~s}^{-1}\right.$, faster but only $\sim 50$ days of observation) were found at $\sim 47^{\circ} \mathrm{N} 15^{\circ} \mathrm{W}$ by the Groupe Tourbillon (1983). These in situ data lie outside the time window for sla data.

\section{Sroddies}

At $45^{\circ} \mathrm{N}$ in the Bay of Biscay, the sla travel curves were not well defined but swoddy-like eddies have a clear positive sla signature (Garcia-Soto et al., 2002) and the spacing between the three sla highs in the Bay of Biscay was $\sim 215 \mathrm{~km}$. Slope Water Ocean eDDIES or swoddies are ocean eddies with a component of water that was formerly in the vicinity of the continental slope (Pingree \& Le Cann, 1992). Swoddies can form from a poleward continental slope current at topographic irregularities, a change in slope direction, for example. These eddies contain a central core where the isopycnal separation is locally increased and are therefore anticyclonic. Swoddies may have an aspect ratio of $\sim 0.5 \%$. In the Bay of Biscay, swoddies can form from the Navidad and were found to be particularly evident in the winters (January) of 1990, 1996 and 1998 and the winters for these years (i.e. 1989/1990, 1995/1996 and 1997/1998) were associated with a large negative NAO Index (GarciaSoto et al., 2002). A marked Navidad occurred in 2000/ 2001 with warmer winter water from Portugal to the Celtic Sea. Biscay swoddies tend to be relatively small with maximum currents of $\sim 30 \mathrm{~cm} \mathrm{~s}^{-1}$ at a radius of $30 \mathrm{~km}$. Drogued Argos buoys deployed in swoddy-like anticyclonic eddies have remained in an eddy core (within a radius of $15 \mathrm{~km}$ of the eddy centre) for 200 days. This implies low horizontal diffusion rates and estimates of horizontal diffusion based on the separation of a pair of particles or drogued buoys gave values $2 \mathrm{~m}^{2} \mathrm{~s}^{-1}$, or about a 100 times smaller than the value determined for Storm 0. Swoddy F90 moved westward at $\sim 2 \mathrm{~cm} \mathrm{~s}^{-1}$ over a $\sim 300$-d period but many Biscay eddies showed little or no net westward movement and some are trapped by slope topography so that their average westward speed is $\ll 2 \mathrm{~cm} \mathrm{~s}^{-1}$. Biscay eddies have a local control on the seasonal distribution and abundance of chlorophyll- $a$ within the eddy (Garcia-Soto et al., 2002).

The broad summary for swoddy-like eddies in the Bay of Biscay is that they have an altimeter signal reflecting a core at $\sim 150 \mathrm{~m}$ depth. These eddies have reduced wavelike properties and rarely exist for 300 days and travel so slowly from the inner Bay of Biscay that they can have little influence on the nature of westward propagating sla 
disturbances in more open ocean conditions at these latitudes which were found to have a westward speed of $\sim 1.0 \mathrm{~cm} \mathrm{~s}^{-1}$.

\section{Rossby Waves vs waves and eddies}

The sections show that there are eddies and wave present or eddies with wave-like properties. In this section, we show that plane linear mode 1 Rossby Waves are only an approximation to the observations. The first point that is often overlooked is that the observed waves are not coherent or have short crests in the meridional direction which makes the structure appear more eddy-like with east-west orbital currents comparable with north-south currents. One reason for an extensive literature describing the altimeter signals in terms of Rossby Waves is that the observed sla structures (eddies and waves) travel westwards at speeds comparable with plane Rossby Waves, mode 1 at the longwave non-dispersive limit (Table 3, compare column 6, theory, with columns 12, derived from sla travel curves or 13, based on measurements of Lagrangian followers in eddies). It was also noticed that the non-dispersive (longwave limit) Rossby Waves travelled westward rather more slowly (see Chelton \& Schlax, 1996) than the observed structures (data from sla or Lagrangian measurements in waves or eddies). However, the wavelength of the structure is significant and this further reduces the westward speed (Table 3, compare column 8 with 6) with respect to the longwave limit. The Lagrangian measurements presented for $\sim 20^{\circ} \mathrm{W}$ (Table 1) with westward flows of $6 \mathrm{~cm} \mathrm{~s}^{-1}$ would offset the difference between theory $\left(4.0 \mathrm{~cm} \mathrm{~s}^{-1}\right.$, now column 8) and sla measurement $\left(5.5 \mathrm{~cm} \mathrm{~s}^{-1}\right.$, column 12). The results for wave period show that the observed period is less than the permitted Rossby Wave period (Table 3, compare columns 9 and 10). Rossby Waves near these observed periods or rather at the minimum period will have westwards speed values half those given in column 6 . Their wavelength, $\lambda$, is then $\lambda=2 \pi \mathrm{R}_{0}$. At $32.5^{\circ} \mathrm{N}$, where we have the most complete coverage of in situ observations, the wavelength for the mode 1 Rossby Wave would be about $\sim 200 \mathrm{~km}$, much shorter than observed $\sim 500 \mathrm{~km}$. The group velocity would be zero, whereas in Pingree et al. (2002) it was shown that the group velocity at $32.5^{\circ} \mathrm{N}$ was comparable with the westward speed of the sla eddy-wave-like structure. Further work shows that the westward speed of the observed structures can be matched or even exceeded at the latitudes considered here if ocean models are used to provide a detailed description of the barotropic contribution in addition to the mode 2 baroclinic flow field on the theoretical speed of extratropical planetary waves (Killworth et al., 1997). We note however that Global Circulation Models (GCMs) do not yet reproduce the structures observed in the in situ observations or the remote sensing data analysed here (e.g. sla structure, Swesties, Storms, Meddies, Swoddies). For a fully convincing case, reconciling observations with theory, it would be necessary to show that the theoretical planetary waves can exist at the periods and wavenumbers observed at a given latitude.

\section{Sla, temperature, slope current measurements and NAO Index}

Although a Eulerian and Lagrangian current programme has been running continuously for $\sim 25$ years, observations of sla have only been made since 1992. The most dramatic change in winter NAO Index that has probably occurred (since 1825) was at the end of the last century, between 1994/1995 and 1995/1996 (see Visbeck et al., 2001). Fortunately, we have in situ measurements of temperature and currents for this period and an obvious correlation of sla, temperature and current structures occurred along the north-east Atlantic Ocean margin $\left(\sim 40^{\circ}-60^{\circ} \mathrm{N}\right)$ in the winter of $1995 / 1996$ (Figure 14). The European Poleward Slope Current shows SOMA seasonality (Pingree, 1993; Huthnance et al., 2001) with weakened poleward flow or occasional flow reversals in March and April in the Bay of Biscay region south of $\sim 52^{\circ} \mathrm{N}$ (Porcupine Seabight slope). To the north, the poleward flow is stronger in January and February (Gould et al., 1985) with a transport reaching $7 \mathrm{~Sv}$. In the winter, the poleward flow brings with it relatively warm water from the south and in some years (NAVIDAD years, with dynamic height forcing from Portugal to Ireland) a warmer eastern boundary extends from Portugal to the Shetlands Isles (Garcia-Soto et al., 2002). In December 1995, January, February and March 1996, Argos Buoy 3350 travelled $1600 \mathrm{~km}$ along the North West European shelf break from $\sim 50^{\circ} \mathrm{N}$ to $61^{\circ} \mathrm{N}$ (Table 1, Figure 14A, see also Pingree et al., 1999b). The sla was low in the ocean with respect to the shelf and in the sense expected for geostrophic balance but the gradient was larger since there are other balance of forces to consider (wind set up, for example). The anomaly is a slope and shelf positive anomaly (Figure 14B) rather than an ocean depression, which was in fact slightly positive $\sim 0$ to $+1 \mathrm{~cm}$ (see next section). The winter of 1995/1996 had the largest negative winter NAO Index over the last $\sim 100$ years $(\sim-3$ to -4 , see Garcia-Soto et al., 2002) so warming along the European Continental Slope correlates with extreme negative NAO Index tendencies, in winter at least. The wind driven component of the variations in strength of the slope current can be understood by noting that in the region considered positive indices are associated with westerlies and negative indices, easterly tendencies (i.e. geostrophic wind balancing atmospheric pressure gradient). The wind rose of frequency, force and direction for $\sim 53^{\circ} \mathrm{N}$ (Bidston Observatory, see Alcock \& Rickards, 2001) for December to February 1995/1996 is superposed in Figure 14A. This shows that the most frequent winds ( 23-24\%, force $1-3,4,5-6)$ were from the south-east, and this strongly contrasts to the mean situation or an extreme positive phase of the NAO Index where westerlies dominate in strength and frequency. Models show that in addition to any density driven slope current there will be a wind driven contribution which has its greatest speed in shallower water depths. At say $49^{\circ} \mathrm{N}$ on the shelf near Goban Spur, a westerly wind produces a southward shelf break flow, whereas an easterly wind produces a northward flow (Pingree \& Le Cann, 1989). The large-scale alignment of the European Continental Slope is more north-south so in general a southerly wind or northerly wind stress is more favorable in generating a wind driven component of the poleward flow, or even a relaxing of southerly directed wind stress with upwelling conditions (Pingree, 1993). An Index that takes more account of the east-west atmospheric pressure gradient would be more appropriate for examining the wind induced poleward flow climate for the region west of Ireland. The model 
results showed that a maximum transport of shelf water around the south-west corner of Ireland occurred with winds from $142^{\circ} \mathrm{T}$, so the winds for the winter 1995/1996 (December to February, Figure 14A) period were favourably directed to augment the slope current at this position. We also note (Garcia-Soto et al., 2002) that 1990, 1996, 1998 and 2001 had a relative low or negative winter NAO Index (mean of November and December for the previous year) and these years were associated with warm surface temperature anomalies along the continental slope margin from Portugal to Norway in January. In addition to wind forcing, density forcing or a poleward dynamic height gradient drives a poleward slope current and it is noted that in both 1996 and 1998 the sla was higher than average near the continental slope region, $\sim 10^{\circ} \mathrm{W}$ (see Figure 12), in the region to the east of the Horseshoe Abyssal Plain (Figure 6). An analysis of ocean sea surface slope near the continental slope from just south of Portugal to the Celtic Sea from 1992-2002 showed that just significant slopes forcing poleward current occurred in 1996, 1998 and 2001 with a head of $\sim 2-3 \mathrm{~cm}$. This ocean or density forcing component of the slope current is considered after the ocean circulation is considered.

Sla, rapid climate change, water masses and geostrophic ocean circulation

The winter of 1993/1994 was associated with an extreme positive winter NAO Index $(\sim+3$ to +4$)$ as was the winter of $1994 / 1995(\sim+2)$ and 1999/2000 $(\sim+2)$. In 1994, cool conditions prevailed at Goban Spur and the poleward flow reversed between March and May in 1994 and 1995 (Pingree et al., 1999b). The mean sla for March and April (1994 and 1995) showed a shelf region that was depressed with respect to the adjacent ocean in agreement with the sense expected for geostrophic equatorward flow. However, the adjacent ocean was also depressed with levels at $\sim-5 \mathrm{~cm}$, considerably lower than in the winter of $1995 /$ 1996 (see previous section). In Pingree et al. (2002), it was shown that the altimeter has a seasonal signal that relates to a thermodynamic or a non-dynamic heat storage or buoyancy (with fresh water conributions) content. This buoyancy signal can be estimated from the local seasonal net heat balance and the balance of precipitation (or run off in the proximity of a freshwater source) over evaporation. This means that the annual buoyancy cycle is seen in the altimeter data with lower values in late winter and higher values in late summer (Figure 15). In the North Atlantic, the annual signal is about $\pm 5 \mathrm{~cm}$. CTD stations in the north-eastern Atlantic subtropical region confirm that dynamic height differences between late summer (mid October; PML, 1995) and late winter (March; PML, 1992) are about 11 dyn.cm at the same positions using a 2000 dbar reference pressure. This mean value was derived from six CTDs at fixed latitudes either side of the AC or Subtropical Front. Some of this signal will also be due to different water masses that have advected into or out of the region, e.g. $18^{\circ} \mathrm{C}$ water in the Subtropical Front region. It is also quite possible that salinity anomalies may become dominate at times (Dickson et al., 1988) especially in regions of reduced salinity, northern polar or subpolar regions. Although direct heat flux values can be estimated, precipitation minus evaporation is harder to quantify but can be estimated from salinity budgets (e.g.
Pingree et al., 2002). To give an idea of the amplitude of the seasonal variation of sea level due to a surface buoyancy flux, estimates for the English Channel conditions are $\sim 4 \mathrm{~cm}$ due to expansions and $\sim 3 \mathrm{~cm}$ due to precipitationevaporation differences (Maddock \& Pingree, 1982). In Figure 15, there are also dynamic signals due to eddies and waves which could be filtered out if required but they give the scale of the dynamic structure (see later) so they have been retained for this paper. In addition, all the major ocean currents can be identified by the dynamic part of the annual seasonal cycle e.g. Gulf Stream, North Atlantic Current, North Equatorial Current, Equatorial Counter-Current and South Equatorial Current. It is easy to see the relation between climate and sla even with the dynamic eddy/wave signal present. In the region between $52^{\circ}$ ( Charlie Gibbs Fracture Zone) and $60^{\circ} \mathrm{N}$, the annual signal has an amplitude of $5 \mathrm{~cm}$ at $\sim 55^{\circ} \mathrm{N}$, but in the winter of 1994 and 1995 the sea level anomaly is more negative than usual showing that the dynamic height is reduced. Likewise, the winters of 1996 and 1998 are less negative than normal showing that this is a period with increased heat or buoyancy storage. These summers have sla values that are elevated more than usual so in this case the warming anomaly, heat storage or increased dynamic height relates to the whole year. The winter of 1999/2000 has a positive NAO Index of $\sim+2$ and the winter sla levels are lower than in 1995/1996 and 1997/1998. Examination of other oceanic meridional sections shows that these sla anomalies occurred from $10^{\circ} \mathrm{W}$ to $40^{\circ} \mathrm{W}$. Further west, the effects were evident further south, $\sim 43^{\circ} \mathrm{N}$, south of Flemish Cap but north of the Gulf Stream influence. These ocean scale long period sla changes will have dynamic consequences for the North Atlantic circulation.

For illustrative purposes, the altimeter data for a central point in the subpolar North Atlantic at $35^{\circ} \mathrm{W}$ $55.5^{\circ} \mathrm{N}$ has been selected to represent the longer period changes in sla with the annual signal removed and is plotted with the winter NAO values discussed above in Figure 16. Although premature, it is noted that ocean colour (SeaWiFS chlorophyll-a) showed a generally more intense productive season (spring, summer) in 1999 and 2000 (NAO positive phase) than in 1998 and 2001 in the Bay of Biscay, the south-western Approaches and the western English Channel. It is now established that winter NAO indices correlate with rainfall with the positive phase of NAO tending to lead to mild and wet winters over northern Europe and the annual Plymouth rainfall (Wood, 1989) is also plotted in Figure 16. It is apparent that for this period of rapid fluctuating climate change that the winter NAO Index (Hurrell, 1995) correlates negatively with longer period sla trends at this position which shows an increase in sea level of about $7 \mathrm{~cm}$ between 1994 and 1997. The rise in sea level near 1996-1998 could not actually be due to rainfall as it has the wrong sign. Although Dickson et al. (2002) show a rapid freshening of the deep North Atlantic over the past four decades they show slightly saltier conditions in the Denmark Strait and Labrador Sea for the 1996-1998 period. So the negative correlation with NAO Index is a direct dynamic response to the rising sea level due to a weakening of sea surface slope or a decrease in North Atlantic Current strength resulting from weaker westerly NAO winds, or ocean scale wind stress curl. The lag is 
about one year. This positive sla signal flanked by lower values near $\sim 1994$ and $\sim 1999$ is widespread across the central Atlantic from $\sim 50^{\circ}-60^{\circ} \mathrm{N}$. The sla signal tends to have the opposite sign from $\sim 30^{\circ}-50^{\circ} \mathrm{N}$ but is again similar in the tropics $\sim 10^{\circ}-30^{\circ} \mathrm{N}$. These longterm changes in sea level can be made more representative by averaging over a region large enough to smooth out the eddy noise in the sla signal (as seen in Figure 15). We can say that in $\sim 1996-1998$ the North Atlantic Gyre weakened with less easterly flow in the North Atlantic Current towards northern Europe and less westerly return flow in the Subtropical Gyre in the Canary Current (CG)/North Equatorial Current (NEG) region. A weakening Gulf Stream following years of low NAO Index is consistent with the reduced westerly wind stress that is in geostrophic balance with the associated weakened atmospheric pressure gradient between the Iceland Low and the Azores High. In like manner, the Gyre was more anticyclonic in $\sim 1994-1995$. As an example of ocean climate change, we take the values of sla centred at $\sim 55^{\circ} \mathrm{N}\left(35^{\circ} \mathrm{W}\right.$, see Figure 16 ; position A, Figure 1 , and with $\sim \pm 250 \mathrm{~km}$ smoothing) and subtract them from values determined in a similar manner at $37.5^{\circ} \mathrm{N}$ (also at $35^{\circ} \mathrm{W}$, position B, Figure 1) to give the sea surface slope (or east current) across the North Atlantic Current (NAC) between A and B, chosen sufficiently far apart to include most of the NAC system. For the return flow in the Subtropical Gyre (STG), a similar difference exercise was performed between $37.5^{\circ} \mathrm{N}(\mathrm{B})$ and $17.5^{\circ} \mathrm{N}$ (also at $35^{\circ} \mathrm{W}$, position $\mathrm{C}$ ) to give a measure of the westward flow or transport in the STG. In Pingree \& Sinha (1998) it was shown that $1 \mathrm{~cm}$ of sea level change corresponded to a transport of $\sim 1 \mathrm{~Sv}$ (3000 dbar reference) for mesoscale structure. For zonal gyre scale slopes, a $1 \mathrm{~cm}$ change was equivalent to $\sim 0.7 \mathrm{~Sv}(3000 \mathrm{dbar}$ reference) at $32^{\circ} \mathrm{N}$ (see Figure $4 \mathrm{~A}$ ). Meridional changes in transport between $\mathrm{B}$ and $\mathrm{C}$ for a $1 \mathrm{~cm}$ sea surface change are expected to be larger $(\sim 0.8 \mathrm{~Sv})$ since the mean coriolis parameter is smaller. The proportional changes in ocean circulation are quite significant and will have a profound effect on the distribution of ocean properties, fluxes and species from year to year. Other calibrations can make use of longterm current measurements, for example, in years of marked flow in the STG, the measured flows were $5 \mathrm{~cm} \mathrm{~s}^{-1}$ in the NEG in 1995 and $7 \mathrm{~cm} \mathrm{~s}^{-1}$ in 1999-2000 (Table 1). The period of Gyre weakening corresponds with the period of Eastern Boundary Flow enhancement with warming along the European Continental Slope Margin (Figure 14) and is the result of both wind effects and changing sea level as the ocean geostrophic pressure gradients change. In conclusion, longer period sla trends are able to monitor climate changes or circulation in the Gyre when differences are made at carefully selected places.

\section{DISGUSSION AND SUMMARY}

The paper presents in situ measurements and altimeter data on mesoscale ocean structure to examine waves and eddies and longterm measurements on ocean climate and circulation in the Eastern North Atlantic Ocean. Some distinguishing features between eddies and waves in the eastern North Atlantic have been made, though as pointed out in Pingree \& Sinha (2001) eddies near $32.5^{\circ} \mathrm{N}$ have wavelike properties. It is also shown how to derive the ocean circulation and monitor the effects of rapid climate change from space using the sla data calibrated against the measurements presented. The wavelike properties are more evident for lower aspect ratio structure and Meddies with the largest vertical to horizontal scale are the most eddylike of structures studied. Signatures of eddies and associated wavelike structure can be seen in remote sensing sla data. Although the sla is a surface measurement, this surface expression of geostrophic current reflects the movement of deeper internal oscillations in the ocean. For Storms, the internal oscillations are a maximum at $300 \mathrm{~m}$ depth in the permanent thermocline but comparable vertical displacements occur near the sea-floor ( $\sim 4 \mathrm{~km}$ depth); for Meddies, the motion is centred near a depth of $1 \mathrm{~km}$; a Swesty has maximum swirl currents at $\sim 100-250 \mathrm{~m}$ depth. Near $26^{\circ} \mathrm{N}$ and $32.5^{\circ} \mathrm{N}$, eddies and waves travel westward at the same speed. Even Meddies that pass southward through the westward propagating wave field, and show reduced wavelike properties, travel westward at the same speed as westward propagating disturbances near $36^{\circ} \mathrm{N}$. At $35.5^{\circ} \mathrm{N}$, Meddies can travel directly westward within the topographic control of seamounts in the Horseshoe Abyssal Plain. Further south (e.g. Armi et al., 1988), Meddy speeds do not match the westward speed of propagating disturbances at the same latitude. The results for westward phase speed, c, wavelength, L, and period, T, for waves are summarized in Figure 17. These results also represent the westward travel speed, c, scale of repeating structure, L (or size, L/2, of eddy), and repeat period, T, for eddies. Clearly only two of the parameters are independent and the errors indicated by the size of the plotted points reflect the variability obtained by different methods. In practice, many periods and wave numbers are present though some characteristics in a spectral band can become dominant. It has been shown that apart from the annual signal which is only dynamic in major ocean current systems, the main period in this latitude range is near semi-annual but rather longer periods $\sim 200$ days occur at $32.5^{\circ} \mathrm{N}$ and higher latitudes with shorter periods at latitudes south of $\sim 30^{\circ} \mathrm{N}$. The wavelength is $\sim 300 \mathrm{~km}$ at $48^{\circ} \mathrm{N}$ and $500-600 \mathrm{~km}$ at $20^{\circ}-30^{\circ} \mathrm{N}$, showing that both wavelength and eddy size decrease with latitude (Krauss et al., 1990) though the proportional change in wavelength is less than in westward speed or period and is almost constant between $20^{\circ} \mathrm{N}-33^{\circ} \mathrm{N}$. Increase of eddy size and propagation speed of measured structure at equatorial latitudes is supported by the measurements of Flament et al. (1996) who reported and surveyed an anticyclonic eddy or vortex with centre at $4^{\circ} \mathrm{N}$ in the tropical Pacific Ocean which was $500 \mathrm{~km}$ in diameter (or $\mathrm{L}=1000 \mathrm{~km}$ ) and which moved westward at $\sim 30 \mathrm{~cm} \mathrm{~s}^{-1}$. The meridional scale or size of westward propagating structure is also seen in plots of latitude against time (Figure 15) and this scale divided by the time width of structure gives the westward propagation speed but this is more conveniently determined from the longitude plots or travel contours (e.g. Figures 3, 5 \& 12). The scale for eddies also tells us that 'Rossby' waves are only coherent (i.e. same crest or trough) meridionally for similar scales, typically 5 degrees of latitude in equatorial and tropical regions and 2 degrees at $\sim 50^{\circ} \mathrm{N}$. 
For the same reason, although the sla latitudes analysed here were carefully chosen, similar qualitative agreement with in situ measurement structure was found one degree north or south of the chosen latitude. The jump in scale near $34^{\circ} \mathrm{N}$ might suggest that the eddy motions are more eddy-like north of the $\mathrm{AC}\left(\sim 34^{\circ} \mathrm{N}\right)$ and more wavelike in properties to the south, supporting an idea of a critical latitude as occurs with theoretical Rossby Waves. Rossby Wave mode 1 characteristics did not accurately fit the observation, particularly with respect to the dispersion relationship between wave number and wave frequency. Although the values for period and scale change by a factor of $\sim 2$ in the latitude range $25^{\circ} \mathrm{N}-$ $48^{\circ} \mathrm{N}$, they result in a 4 -fold change in westward speed with values of typically $1 \mathrm{~cm} \mathrm{~s}^{-1}$ at $45^{\circ} \mathrm{N}, 2 \mathrm{~cm} \mathrm{~s}^{-1}$ at $35^{\circ} \mathrm{N}, 3 \mathrm{~cm} \mathrm{~s}^{-1}$ at $32.5^{\circ} \mathrm{N}$ and $4 \mathrm{~cm} \mathrm{~s}^{-1}$ at $25^{\circ} \mathrm{N}$ (and $5.5 \mathrm{~cm} \mathrm{~s}^{-1}$ at $20^{\circ} \mathrm{N}$ ). Overall throughout the North Atlantic, it is shown that in situ measurements of cold structure or upward doming of isotherms (or cyclonic structure) corresponds with negative sla structure and that dips in the ocean thermocline, or warm anticyclonic structures, match positive sla disturbances.

In the north-east of the region $\sim 50^{\circ}-60^{\circ} \mathrm{N}$ or Eastern Boundary, current and temperature structure in the vicinity of the continental slope margin was appraised in terms of a sla step up or a step down from ocean to continental shelf and the winter NAO Index. It was shown that warm winter conditions and poleward flow along the northern European continental slope margin related to positive sla gradients from ocean to shelf and occurred with extreme negative winter NAO indices and that cold conditions prevailed during the positive NAO phase. Although the sla structure from ocean to shelf was in the sense expected for a geostrophic slope currents, the sla gradient was larger than that for a geostrophic balance with the shelf or shallower region making the main contribution to the sla change. Years of marked winter ocean margin warming for western Europe or enhanced poleward flow were 1990, 1996, 1998 and 2001. Cool conditions prevailed in 1994 with slope flow reversal at $49^{\circ} \mathrm{N}$, Goban Spur. The biological impact may be marked, for example, tropical and subtropical species may find themselves displaced poleward of their northern limits of distribution along the eastern margin of the Ocean in years of flow.

In more open ocean conditions, it was shown that longterm trends in sla correlated with winter NAO indices. The sea level anomalies (with the annual signal removed) were coherent over large regions of the North Atlantic Ocean and the sea surface slopes will be in partial geostrophic balance (since also wind stress set-up). Although the derived currents may be small, they will apply over a large region so the associated transport of water in major current systems will be significant. Altimeter data is ideal for examining variations in geostrophic transport or climate changes. Mean values can be derived if the geoid is known or the altimeter data are calibrated against in situ measurement data as was done at $32.5^{\circ} \mathrm{N}$. The sea level differences or gradients can be considered as representing circulation transport and the values derived between points BA and BC are plotted against year in Figure 18. It is apparent that when the flow or transport of the NAC decreases in 1996-1998 there is also less return flow in the
STG and without lag. Flow was higher than average in 1994-1995 and 1999-2000. Moreover, the values correlate with winter NAO as would be expected since the wind stress drives the ocean circulation and induces set-up. The response lag is $\sim 1$ year. We have seen that when the NAO Index is in extreme negative mode then the poleward continental slope flow is enhanced, as occurred in 1996 (Figure 14), 1998 (Garcia-Soto et al., 2002) and 2001 and therefore the North Atlantic Current strength and poleward flow are out of phase. This can be understood by noting that the poleward flow into the Bay of Biscay and along the Celtic Sea shelf-break/slope region is driven by ocean sea level elevations near the continental slope south of Portugal or dynamic height gradient impressed from the ocean along the continental slope. When the STG slows, the return flow in the North Equatorial Current is reduced and more locally the Canary Current and southward flow in the Gyre decreases. This weakened geostrophic balance tilts the sea surface slope upwards relatively in the east of the Gyre near the Eastern Boundary and so the dynamic height increases along the continental slope and or a residual poleward decline alongslope gradient is now left unbalanced. The east-west tilt of the ocean can be calibrated from the zonal CTD sections presented. In 1996 the transport for the central $\left(\sim 33^{\circ} \mathrm{N}\right)$ STG was $28 \mathrm{~Sv}$ from $50^{\circ} \mathrm{W}$ to the Eastern Boundary near $20^{\circ} \mathrm{W}$ and this value is superposed on the Gyre (STG) curve in Figure 18, implying that the transport in 1999/2000 was $\sim 36 \mathrm{~Sv}$ when the flow in NEC at $\sim 16.5^{\circ} \mathrm{N}$ was $\sim 5 \mathrm{~cm} \mathrm{~s}^{-1}$. The results are complete from 1992 to 2002 and are updated annually.

Unprocessed raw altimeter data were received from ESA grant A02.UK121 and A03 158 and ENVISAT grant A0-ID 192. Ian Waddington designed and deployed Rigs 149, 152 and 155. The Lagrangian data were supported by Ocean Climate, programme 780 ARGOS.

\section{REFERENCES}

Alcock, G. \& Rickards, L., ed., 2001. Climate of UK Waters at the Millennium Status and Trends. IACMST Information Document, no. 9, 48 pp.

Arhan, M., 1987. On the large scale dynamics of the Mediterranean outflow. Deep-Sea Research, 34, 1187-1208.

Arhan, M., Billant, A., Colin de Verdiere, A., Daniault, N. \& Prego, R., 1991. Hydrography and velocity measurements offshore from the Iberian Peninsula Bord-Est. Compagnes Océanographiques Française, no. 15, IFREMER, 232 pp.

Arhan, M., Colin de Verdiere, A. \& Mercier, H., 1989. Direct observations of the mean circulation at $48^{\circ} \mathrm{N}$ in the Atlantic Ocean. Journal of Physical Oceanography, 19, 161-181.

Armi, L., Hebert, D., Oakey, N., Price, J., Richardson, P.L., Rossby, T. \& Ruddick, B., 1988. The history and decay of a Mediterranean salt lens. Nature, London, 333, 649-641.

AVISO/Altimetry, 1996. AVISO CD ROM Users Manual for Merged TOPEX/POSEIDON products, AVI-NT-02-100, edn. 3.0.: CLS.

Born, G., Leben, R., Fox, C. \& Tierney, C., 1998. Wave monitoring and analysis in the Pacific. AVISO Altimetry Newsletter, 6, $16-17$.

Bower, A.S., Armi, L. \& Ambar, I., 1997. Lagrangian observations of meddy formation during a Mediterranean undercurrent seeding experiment. Journal of Physical Oceanography, 27, $2545-2575$. 
Boyd, J.D. \& Linzell, R.S., 1993. The temperature and depth accuracy of Sippican T-5 XBTs. Fournal of Atmospheric and Oceanic Technology, 10, 128-136.

Chelton, D.B. \& Schlax, M.G., 1996. Global observations of oceanic Rossby waves. Science, New York, 272, 234-238.

Cipollini, P., Cromwell, D., Challenor, P.G. \& Raffaglio, S., 2001. Rossby waves detected in global ocean colour data. Geophysical Research Letters, 28, 323-326.

Cipollini, P., Cromwell, D., Graham, D., Quartly, G.D. \& Challenor, P.G., 2000. Remote sensing of oceanic extratropical Rossby waves. In Satellites, oceanography and society (ed. D. Halpern). Elsevier Oceanographic Series, 63, 99-123.

Cipollini, P., Cromwell, D., Jones, M.S., Quartly, G.D. \& Challenor, P.G., 1997. Concurrent altimeter and infrared observations of Rossby wave propagation near $34^{\circ} \mathrm{N}$ in the northeast Atlantic. Geophysical Research Letters, 24, 889-892.

Cromwell, D., Challenor, P.G., New, A.L. \& Pingree, R.D., 1996. Persistent westward flow in the Azores Current as seen from altimetry and hydrography. Fournal of Geophysical Research, 101, 11923-11933.

Cushman-Roisin, B., Chassignet, E.P. \& Tang, B., 1990. Westward motion of mesoscale eddies. Fournal of Physical Oceanography, 20, 758-768.

Davis, R.E., Webb, D.C., Regier, L.A. \& Dufour, J., 1992. The Autonomous Lagrangian Circulation Explorer (ALACE). Fournal of Atmospheric and Oceanic Technology, 9, 264-285.

Dickson, R.R., Gould, W.J., Müller, T.J. \& Maillard, C., 1985. Estimates of the mean circulation in the deep $(>2000 \mathrm{~m})$ layer of the eastern North Atlantic. Progress in Oceanography, 14, 103-127.

Dickson, R.R., Meinke, J., Malmberg, S.-A. \& Lee, A., 1988. "The Great Salinity Anomaly" in the North Atlantic 19681982. Progress in Oceanography, 20, 103-151.

Dickson, R.R., Yashayaev, I., Meinke, J., Turrell, W.R., Dye, S. \& Holfort, J., 2002. Rapid freshing of the deep North Atlantic over the past four decades. Nature, London, 416, 832-837.

Flament, P.J., Kennan, S.C., Knox, R.A., Niiler, P.P. \& Bernstein, R.L., 1996. The three-dimensional structure of an upper ocean vortex in the tropical Pacific Ocean. Nature, London, 383, 610-613.

Flierl, G.R., 1981. Particle motion in large-amplitude wave fields. Geophysical and Astrophysical Fluid Dynamics, 18, 39-74.

Fratantoni, D.M., 2001. North Atlantic surface circulation during the 1990s observed with satellite-tracked drifters. Fournal of Geophysical Research, 106, 22067-22093.

Garcia-Soto, C, Pingree, R.D. \& Valdés, L., 2002. Navidad development in the Southern Bay of Biscay: climate change and swoddy structure from remote sensing and in situ measurements. Fournal of Geophysical Research, 107, in press.

Gill, A.E., 1982. Atmosphere-ocean dynamics. London: Academic Press.

Gould, W.J., Loynes, J. \& Backhaus, J., 1985. Seasonality in slope current transports NW of Shetland. International Council for the Exploration of the Sea (CM Papers and Reports), CM 1985/C: 7, 7 pp.

Groupe Tourbillon, 1983. The Tourbillon experiment: a study of a mesoscale eddy in the eastern North Atlantic. Deep-Sea Research, $5,475-511$

Hagen, E., 1986. On the annual Rossby dispersion off Dakar, northwest Africa. Tropical Ocean-Atmosphere Newsletter, October, 15-18.

Halliwell, G.R. \& Cornillon, P., 1991. Westward-propagating SST anomaly features in the Sargasso Sea. Fournal of Physical Oceanography, 21, 635-649.

Halliwell, G.R., Ro, Y.J. \& Cornillon, P., 1991. Westward-propagating SST anomalies and baroclinic eddies in the Sargasso Sea. Fournal of Physical Oceanography, 21, 1664-1680.
Hedstrom, K. \& Armi, L., 1988. An experimental study of homogeneous lenses in a stratified rotating fluid. Fournal of Fluid Mechanics, 191, 535-556.

Hurrell, J.W., 1995. Decadal trends in the North Atlantic Oscillation: region temperatures and precipitation, Science, New York, 269, 676-679.

Huthnance, J.M., et al., 2001. Physical structures, advection and mixing in the region of Goban spur. Deep-Sea Research II, 48, 2979-3021.

Kelly, K.A. \& Watts, D.R., 1994. Monitoring Gulf Stream transport by radar altimetry and inverted echo sounders. Fournal of Physical Oceanography, 24, 1080-1084.

Killworth, P.D., Chelton, D.B. \& deSzoeke, R.A., 1997. The speed of observed and theoretical long extra-tropical planetary waves. Fournal of Physical Oceanography, 27, 1946-1966.

Krauss, W., Dscher, R., Lehmann, A. \& Viehoff, T., 1990. On eddy scales in the eastern and northern North Atlantic Ocean as a function of latitude. Fournal of Geophysical Research, 95, 18049-18056.

Lacombe, H. \& Tchernia, P., 1960. Quelque traits généraux de l'hydrologie méditerranéene d'après diverse campagnes hydrologiques récentes en Méditerranée dans le proche Atlantique et dans le détroit de Gibraltar. Cahiers Océanographique, 2, 527-547.

Le Traon, P.Y., Gaspar, P., Bouyssel, H. \& Makhmara, H., 1995. Using TOPEX/POSEIDON data to enhance ERS-1 data. Journal of Atmospheric and Oceanic Technology, 12, 161-170.

Le Traon, P.Y., Nadal, F. \& Ducet, N., 1998. An improved mapping method of multisatellite altimeter data. Fournal of Atmospheric and Oceanic Technology, 15, 522-534.

Levitus, S. \& Boyer, T.P., 1994. World Ocean Atlas 1994. Washington DC: National Oceanographic Data Center.

Maddock, L. \& Pingree, R.D., 1982. Mean heat and salt budgets for the eastern English Channel and Southern Bight of the North Sea. Fournal of the Marine Biological Association of the United Kingdom, 62, 559-575.

McGillicuddy Jr, D.J., Kosnyrev, V.K., Ryan, J.P. \& Yoder, J.A., 2001. Covariation of mesoscale ocean color and sea-surface temperature patterns in the Sargasso Sea. Deep-Sea Research II, 48, 1823-1836.

McWilliams, J.C. \& Flierl, G.R., 1979. On the evolution of isolated, nonlinear vortices. Fournal of Physical Oceanography, 9, 1155-1182.

Mied, R.P. \& Lindemann, G.J., 1979. The propagation and evolution of cyclonic Gulf Stream rings. Fournal of Physical Oceanography, 9, 1183-1206.

Mouriño, B., Fernández, F., Escánez, J., Armas, D., Giraud, S., Sinha, B. \& Pingree, R.D., 2002. A SubTropical Oceanic Ring of Magnitude (STORM) in the Eastern North Atlantic: physical chemical and biological properties. Deep-Sea Research $I I, 49$, in press.

Nechvolodov, L.V., 1993. Dynamics of the heat conditions of the North Atlantic Waters in winter of 1992-1993. Meteorologiya $i$ Gidrologiya, N6, 62-69.

New, A.L., Jia, Y., Coulibaly, M. \& Dengg, J., 2001. On the role of the Azores Current in the ventilation of the North Atlantic Ocean. Progress in Oceanography, 48, 163-194.

Paillet, J., Le Cann, B., Serpette, A., Morel, Y. \& Carton, X., 1999. Real-time tracking of a Galician Meddy. Geophysical Research Letters, 26, 1877-1880.

Pingree, R.D., 1993. Flow of surface water to the west of the British Isles and in the Bay of Biscay. Deep-Sea Research, 40, 369-388.

Pingree, R.D., 1995. The droguing of Meddy Pinball and Seeding with ALACE floats. Fournal of the Marine Biological Association of the United Kingdom, 75, 235-252.

Pingree, R.D., 1996. A Shallow Subtropical Subducting WESTward propagating eDDY (SWESTY). Philosophical Transactions of the Royal Society A, 354, 1-45. 
Pingree, R.D., 1997. The eastern Subtropical Gyre (North Atlantic): flow rings recirculations structure and subduction. Journal of the Marine Biological Association of the United Kingdom, 77, 573-624.

Pingree, R.D., Garcia-Soto, C. \& Sinha, B., 1999a. Position and structure of the Subtropical/Azores Front region from combined Lagrangian and remote sensing (IR/altimeter/ SeaWiFS) measurements. Fournal of the Marine Biological Association of the United Kingdom, 79, 769-792.

Pingree, R.D., Kuo, Y.-H. \& Garcia-Soto, C., 2002. Can the Subtropical North Atlantic permanent thermocline be observed from space? Fournal of the Marine Biological Association of the United Kingdom, 82, 709-728.

Pingree, R.D. \& Le Cann, B., 1991. Drifting buoy in the field of flow of two eddies on East Thulean Rise (North Atlantic). Journal of Geophysical Research, 96, 16759-16777.

Pingree, R.D. \& Le Cann, B., 1989. Celtic and Armorican slope and shelf residual currents. Progress in Oceanography, 23, 303-338.

Pingree, R.D. \& Le Cann, B., 1992. Three anticyclonic slope water oceanic eddies (swoddies) in the southern Bay of Biscay in 1990. Deep-Sea Research I, 39, 1147-1175.

Pingree, R.D. \& Le Cann, B., 1993. A Shallow Meddy (a Smeddy) from the Secondary Mediterranean Salinity Maximum. Fournal of Geophysical Research, 98, 20169-20185.

Pingree, R.D. \& Sinha, B., 1998. Dynamic topography (ERS-1/2 and Seatruth) of Subtropical Ring (STORM 0) in the Storm corridor $\left(32-34^{\circ} \mathrm{N}\right.$, Eastern Basin, North Atlantic Ocean). Fournal of the Marine Biological Association of the United Kingdom, 78, 351-376.

Pingree, R.D. \& Sinha, B., 2001. Westward moving waves or eddies (Storms) on the Subtropical/Azores Front near $32.5^{\circ} \mathrm{N}$ ? Interpretation of the Eulerian currents and temperature records at moorings $155\left(35.5^{\circ} \mathrm{W}\right)$ and $156\left(34.4^{\circ} \mathrm{W}\right)$. Fournal of Marine Systems, 29, 239-276.

Pingree, R.D., Sinha, B. \& Griffiths, C., 1999b. Seasonality of the European slope currents (Goban Spur) and ocean margin exchange. Continental Shelf Research, 19, 929-975.

Pingree, R.D., Sinha, B., New, A.L., Waddington, I., Head, R.N. \& Nechvolodov, L.V., 1996. Will deep subtropical Ring 'Storm Physalia' cross the Mid Atlantic Ridge and reach America? Fournal of the Marine Biological Association of the United Kingdom, 76, 553-567.

PML, 1990. RRS Discovery Cruise 193 Report, 30 June-1 August 1990. Plymouth: Plymouth Marine Laboratory.

PML, 1992. RRS Charles Darwin Cruise 66/92 Report, 4 March-6 April 1992. Plymouth: Plymouth Marine Laboratory.

PML, 1994. RRS Charles Darwin Cruise 83/94 Report, 13 December 1993-13 Fanuary 1994. Plymouth: Plymouth Marine Laboratory.

PML, 1995. RRS Charles Darwin Cruise 97/95 Report, 12 October 1995-6 November 1995. Plymouth: Plymouth Marine Laboratory.
Price, J.F., et al., 1993. Mediterranean Outflow Mixing Dynamics. Science, New York, 259, 1277-1282.

Richardson, P.L., 1983. Gulf Stream Rings. In Eddies in Marine Science (ed. Allan Robinson), pp. 19-45. Berlin: SpringerVerlag.

Richardson, P.L., Bower, A.S. \& Zenk, W., 2000. A census of Meddies tracked by floats. Progress in Oceanography, 45, 209-250.

Richardson, P.L. \& Wooding, C.M., 1999. RAFOS Float trajectories in Meddies during the Semaphore Experiment, 19931995. Woods Hole Oceanographic Institution Technical Report, WHOI-99-05, $86 \mathrm{pp}$.

Robinson, A.R., 1983. Eddies in Marine Science. Berlin: SpringerVerlag.

Rossby, C.-G., 1948. On displacements and intensity changes of atmospheric vortices. Fournal of Marine Research, 7, 175-187.

Saunders, P.M., 1981. Practical convertion of pressure to depth. Journal of Physical Oceanography, 11, 573-574.

Saunders, P.M., 1988. Bottom currents near a small hill on the Madeira Abyssal Plain. Fournal of Physical Oceanography, 18, 868-879.

Shapiro, G.I. \& Meschanov, S.L., 1996. Spreading pattern and mesoscale structure of Mediterranean outflow in the Iberian Basin estimated from historical data. Fournal of Marine Systems, 7, 337-348.

Siegel, D.A., 2001. The Rossby rototiller. Nature, London, 409, 576-577.

Stammer, D., Hinrichsen, H.-H. \& Kase, R.H., 1991. Can Meddies be detected by satellite altimetry? fournal of Geophysical Research, 96, 7005-7014.

Taylor, G.I., 1921. Experiments with rotating fluids. Proceedings of the Royal Society A, 100, 114-121.

Tokmakian, R.T. \& Challenor, P.G., 1993. Observations in the Canary Basin and the Azores Frontal Region using Geosat data. Fournal of Geophysical Research, 98, 4761-4773.

Uz, B.M., Yoder, J.A. \& Osychny, V., 2001. Pumping of nutrients to ocean surface waters by the action of propagating planetary waves. Nature, London, 409, 597-600.

Visbeck, M., Hurrell, J. \& Kushnir, Y., 2001. First International Conference on the North Atlantic Oscillation (NAO): lessons and challenges for CLIVAR. CLIVAR Exchanges, 6, 24-25.

White, M. \& Bowyer, P., 1997. The shelf edge current north-west of Ireland. Annales Geophysicae, 15, 1076-1083.

Wilimovsky, N., 1990. Misuses of the term "Julian Day". Transactions of the American Fisheries Society, 116.

Wood, N.L.H., 1989. Rainfall variability at London and Plymouth. Weather, 44, 202-208.

Zenk, W. \& Armi, L., 1990. The complex spreading pattern of Mediterranean water off the Portuguese continental slope. Deep-Sea Research, 37, 1805-1823.

Submitted 29 January 2002. Accepted 31 Fuly 2002. 